\title{
PAVED WITH GoOd INTENTIONS: UNINTENDED Consequences of Federal Proposals to InTEgrate ChILd Support ANd PARENTING TIMe
}

\author{
STACY BRUSTIN ${ }^{*}$ \\ LISA VOLLENDORF MARTIN**
}

\section{INTRODUCTION ${ }^{* * *}$}

Parents typically get to decide for themselves how to divide the rights and responsibilities they share for raising and supporting their children. ${ }^{1}$ Such responsibilities include caring for, making important decisions about, and financially supporting children. ${ }^{2}$ Parents who live together allocate these

* Associate Professor of Law, Co-Director of the Civil Practice Clinic, Columbus School of Law, The Catholic University of America; J.D., Harvard Law School.

** Clinical Assistant Professor of Law, Co-Director, Families and the Law Clinic, Columbus School of Law, The Catholic University of America; J.D., Georgetown University Law Center. For their helpful comments and insights, the authors thank Professors Phyllis Goldfarb, Dan Hatcher, Jane Murphy, Jana Singer, and participants in the 2014 American Association of Law Schools Clinical Legal Education Conference Works in Progress Session, and the 2014 Southern Regional Clinical Conference Works in Progress Session. We are grateful for the excellent assistance of CUA law librarian Steve Young and the tireless research assistance of Brittani Everson and Emily Shinogle.

*** We decided to co-author this Article to bring our differing family law litigation and policy experiences to bear on the subject of integrating custody and visitation determinations in child support proceedings. Lisa Martin and her clinic students primarily have represented survivors of domestic violence in protection orders, domestic relations and immigration matters. Her practice has included establishment, modification, and enforcement of child support. Most of her clients are low income, custodial parents. Stacy Brustin and her clinic students have represented low income clients in a variety of civil matters, specializing over the last ten years in child support, public benefits, and unemployment compensation. She has represented both custodial and noncustodial parents in paternity and child support cases. Her clinic also partners with two legal services agencies to provide limited advice and assistance services to pro se litigants (primarily noncustodial parents) who have cases pending on the paternity and child support dockets at D.C. Superior Court. While writing this Article we shared the insights we have developed through our representation of custodial and non-custodial parents, asked hard questions of one another, pushed ourselves to confront misperceptions that we may have acquired, and attempted to generate realistic and balanced court-reform and policy recommendations.

1. See, e.g., Santosky v. Kramer, 455 U.S. 745, 753 (1982); Parham v. J. R., 442 U.S. 584, 602 (1979); Quilloin v. Walcott, 434 U.S. 246, 255 (1978); Stanley v. Illinois, 405 U.S. 645, 651 (1972); Wisconsin v. Yoder, 406 U.S. 205, 232 (1972); Janet Weinstein, And Never the Twain Shall Meet: The Best Interests of Children and the Adversary System, 52 U. MIAMI L. REV. 79, 123-34 (1997).

2. Homer H. Clark, JR., The Law OF DOMEstic Relations in the United States 481 (2d ed. 1987). 
responsibilities informally every day. ${ }^{3}$ Parents who live apart may divide and share these responsibilities informally, or may choose to formalize the terms of their parenting arrangements by entering into a contract or obtaining a court order addressing custody and child support. ${ }^{4}$ Absent a contract or a court order to the contrary, in most states, a child's legally recognized parents ${ }^{5}$ have full, coextensive rights and responsibilities regarding the child. ${ }^{6}$

Unless concerns about abuse and neglect arise or a parent initiates a divorce, custody, or support case, ${ }^{7}$ the state typically has no role in allocating parents' rights and responsibilities over children. ${ }^{8}$ The state has an overarching duty to act in the interests of children, ${ }^{9}$ but this duty is secondary to parental rights to make autonomous decisions about childrearing. ${ }^{10}$

During the past several decades, federal child support law and policy has altered significantly the traditional scope of parental autonomy ${ }^{11}$ for parents seeking cash welfare benefits to financially support their children. ${ }^{12}$ In exchange for Temporary Assistance for Needy Families ("TANF") ${ }^{13}$ payments, custodial parents give up the right to decide how to share the responsibility for financially

3. Linda D. Elrod, Child Custody Practice And Procedure $\S \S 4.1,4.34$ (2013).

4. Id.

5. Legally recognized parents include biological mothers, parents whose paternity or maternity is established by operation of statute or through voluntary acknowledgement of parentage, and individuals whose paternity or maternity is established through adjudication or adoption. See infra Part I.A.

6. See infra Part I.A.; see also Karen Czapansky, Volunteers and Draftees: The Struggle for Parental Equality, 38 UCLA L. REV. 1415, 1423 (1991); James G. Dwyer, A Constitutional Birthright: The State, Parentage, and the Rights of Newborn Persons, 56 UCLA L. REV. 755, 76668 (2009).

7. See infra Part I.A.

8. Santosky v. Kramer, 455 U.S. 745, 753 (1982); Prince v. Massachusetts, 321 U.S. 158, 166 (1944). The term "state" here refers to both the state government and the courts. But see infra note 55 and accompanying text.

9. Troxel v. Granville, 530 U.S. 57, 65-66 (2000).

10. Wisconsin v. Yoder, 406 U.S. 205, 234 (1972).

11. This shift in child support policy is arguably one component of a broader trend toward the "federalization of family law." See, e.g., Ann Laquer Estin, Federalism and Child Support, 5 VA. J. SOC. POL'Y \& L. 541, 545 (1998); see generally Libby S. Adler, Federalism and Family, 8 COLUM. J. GENDER \& L. 197 (1999); Jill Elaine Hasday, Federalism and the Family Reconstructed, 45 UCLA L. REV. 1297 (1998); Laura W. Morgan, The Federalization of Child Support A Shift in the Ruling Paradigm: Child Support As Outside the Contours of "Family Law," 16 J. AM. ACAD. MATRIM. LAW. 195 (1999).

12. 42 U.S.C. $\S 608(a)(3)(2014)$.

13. Id. The Temporary Assistance to Needy Families Program is the current iteration of the benefits program commonly referred to as "welfare." Tonya Brito, The Welfarization of Family Law, 48 U. KAN. L. REV. 229, 233 (2000). It formerly was known as Aid to Families with Dependent Children (“AFDC”). 42 U.S.C. $\S \S 601-09$ (2014). 
supporting their children with co-parents. ${ }^{14}$ Instead, TANF recipients must assign their rights to collect child support to the state. The state then initiates proceedings to establish parentage, if not already determined, and enter a child support order against the noncustodia $1{ }^{15}$ parent even if the custodial parent would prefer not to do so. ${ }^{16}$

Congress also permits states to use federal funding to pursue child support orders on behalf of parents who formerly received TANF, or never received TANF. ${ }^{17}$ These parents are not required to use the services of the state child support agency, but choose to do so because the state offers a low cost avenue for pursuing child support. ${ }^{18}$ This broadened mission of state agencies has expanded the size and reach of child support programs dramatically at the same time that TANF rolls have declined. ${ }^{19}$ Today, state child support agencies initiate approximately fifty percent of all child support cases in the United States. ${ }^{20}$

Federal policy not only has shaped the level of state intervention in the child support context but also the nature of child support proceedings. ${ }^{21}$ As a condition of federal funding for TANF and child support programs, states must establish expedited processes for establishing child support orders through judicial, quasijudicial, or administrative proceedings. ${ }^{22}$ Unlike traditional domestic relations courts in which parties have the option (or in some cases are required) to adjudicate custody, visitation, and child support in one proceeding, state-initiated child support proceedings typically only address parentage and support. ${ }^{23}$ The limited jurisdiction of such proceedings allows courts to expedite the establishment of support orders while reserving custody and visitation matters for the traditional process of judicial review. Yet, this segregation of child support claims has created inequities. ${ }^{24}$

The segregation of child support claims has resulted in the development of dual adjudicatory systems for allocating parental caretaking responsibilities:

14. Brito, supra note 13 , at 235 .

15. In this Article, we will refer to the parent who owes a duty to pay child support as the "noncustodial parent" and the parent who is owed child support as the "custodial parent" because these are the terms most often used in our practice and by the federal Office of Child Support Enforcement. These terms do not necessarily reflect the distribution of custody rights between the parents involved. Other terms used to distinguish between the parent parties in child support proceedings include resident/nonresident parent and obligor/obligee parent.

16. 42 U.S.C. $\S 608(a)(3)(2014)$.

17. Id. $\S 657$.

18. Carmen Solomon-Fears, Cong. Research Serv., Analysis of Federal-State FinANCING OF THE CHILd Support ENFORCEMENT PRogram 4-5 (2012).

19. Brito, supra note 13, at 275.

20. SOLOMON-FEARS, supra note 18 , at 4-5.

21. See infra Part II.C.

22. 42 U.S.C. $\S 666$ (2014).

23. See infra Part I.A.

24. Paula Roberts, Expedited Processes and Child Support Enforcement: A Delicate Balance Part I, 19 Clearinghouse ReV. 483, 483-84 (1985). 
domestic relations courts and parentage and child support tribunals. Each system offers substantively and procedurally different options for addressing issues related to children. ${ }^{25}$ Low-income parents, particularly those receiving TANF and Medicaid, most frequently enter the system through parentage and child support tribunals where visitation and custody issues generally are not addressed. ${ }^{26}$ Parents who want court intervention to address these issues must file separate and time consuming actions in another court. ${ }^{27}$ These parents usually pursue such separate custody and visitation cases without the benefit of legal representation. ${ }^{28}$

Divorcing and unmarried couples with higher incomes seeking court intervention generally do so through dissolution and domestic relations courts. ${ }^{29}$ These parents frequently have the option either to address custody, visitation, and child support in an integrated fashion or to resolve certain issues through the courts while privately resolving others outside of the court system. ${ }^{30}$

The government has justified its involvement in parentage and child support proceedings, which traditionally were considered private domestic relations matters, as necessary to facilitate cost recapture. ${ }^{31}$ Government initiated child support collection has aimed to reimburse states for TANF payments and help financially strapped parents secure additional resources that prevent them from needing TANF payments in the future. ${ }^{32}$ The resulting intervention into the support-related parenting arrangements of low-income families was viewed as a reasonable trade to ensure that "deadbeat" dads do their fair share to support their children and repay the states for the financial support needed by single mothers

25. See infra Part I.A.; Daniel L. Hatcher, Forgotten Fathers, 93 B.U. L. REV. 897, 910-11 (2013).

26. See infra Part I.A.; see also Vicki Turetsky, What if All the Money Came Home? Welfare Cost Recovery in the Child Support Program, 43 FAM. CT. REV. 402, 403 (2005).

27. See infra Part II.

28. See Legal Servs. Corp., Documenting the Justice Gap in America: The Current Unmet Civil Legal NeEdS of Low InCOME AmeriCANS 11 (2009), available at http://www. 1sc.gov/sites/default/files/LSC/images/justicegap.pdf, archived at http://perma.cc/9NXK-FLJP\#_ blank; see also Karen Czapanskiy, To Protect and Defend: Assigning Parental Rights When Parents Are Living in Poverty, 14 WM. \& MARY BILL RTS. J. 943, 948 (2006); Catherine Wimberly, Deadbeat Dads, Welfare Moms, and Uncle Sam: How the Child Support Recovery Act Punishes Single Mother Families, 53 STAN. L. REV. 729, 736 (2000).

29. Margaret F. Brinig \& Douglas W. Allen, "These Boots Are Made for Walking”: Why Most Divorce Filers Are Women, 2 AM. L. \& ECON. REV. 126, 150-51 (2000).

30. See infra Part I. Many middle income litigants in domestic relations proceedings cannot afford legal counsel and proceed pro se as well. Leslie Feitz, Pro Se Litigants in Domestic Relations Cases, 21 J. AM. ACAD. MATrim. LAW. 193, 194 (2008).

31. See OCSE Fact Sheet, DeP'T of Health And Human Servs., http://www.acf.hhs. gov/programs/css/resource/ocse-fact-sheet (last visited Dec. 28, 2014), archived at $\mathrm{http}: / /$ perma.cc/ 3FGG-GNJD; see also Turetsky supra, note 26, at 410.

32. See OCSE Fact Sheet, supra note 31; see also Turetsky supra, note 26, at 410. 
as a result of their absence. ${ }^{33}$ As policymakers have begun to understand that noncustodial parents (usually fathers) are more often "deadbroke" rather than "deadbeat," the mission and goals of the federal Office of Child Support Enforcement ("OCSE") have begun to change. ${ }^{34}$ Rather than continuing its past focus on securing as much of a noncustodial parent's income as possible to pay off current and past-due support obligations, OCSE is encouraging the establishment of "right sized orders" and promoting employment programs as well as parenting time ${ }^{35}$ programs to enhance noncustodial parents' capacity and incentive to pay support. ${ }^{36}$

The concept of integrating parenting time arrangements into child support orders has garnered significant attention at the national level. The President, Congress, and the United States Department of Health and Human Services have introduced parenting time proposals, all of which have the potential to further limit parental autonomy and dramatically expand state involvement in the lives of low-income families. ${ }^{37}$ In 2013, 2014, and again in 2015, President Obama's proposed budget placed a new condition on receipt of federal TANF funds, ${ }^{38}$ which would mandate that all state-initiated child support orders include

33. Wimberly, supra note 28 , at 736 .

34. DeP't of Health and Human Servi., OfFice of Inspector Gen., State Policies Used TO ESTABLISH CHILD SUPPORT ORDERS FOR LOW INCOME NON-CUSTODIAL PARENTS 4-5 (2000).

35. "Parenting time" is a term increasingly used by states to refer to periods in which a noncustodial parent is entitled to spend time with a child. ELROD, supra note 3 , at $\S 4.1$. Historically, parenting time was commonly referred to as "visitation." Id. States have begun to alter the terminology in response to noncustodial parent objections to being relegated to "visitor" status. Id. Both parenting time and visitation periods are often distinguished from rights of "physical custody" or "primary residential custody," which entitles a parent to reside with and spend all time not accounted for in periods of parenting time or visitation with a child. Id. But see J. Herbie DiFonzo, From the Rule of One to Shared Parenting: Custody Presumptions in Law and Policy, 52 FAM. Ст. REV. 213, 225 (2014) ("Minnesota has substituted a "parenting time" decision for the former decree allocating residential custody and visitation") (citing MINN. STAT. ANN. § 518.175 (2014)).

36. See Dep't of Health and Human Servis., Office of Child Support Enforcement, CHILD SUPPORT HANDBOOK 5-7 (2013), available at http://www.acf.hhs.gov/programs/css/ resource/handbook-on-child-support-enforcement. In 2012, for example, the federal Office of Child Support Enforcement ("OCSE") issued demonstration grants to encourage state child support enforcement agencies to expand their services to offer assistance to noncustodial parents (usually, fathers) seeking visitation (or "parenting time") with their children. ADMIN. FOR CHILDREN AND FAMILIES, DeP'T OF HeAlth \& HuMAN SERVS., OfFICE OF CHILD SUPPORT ENFORCEMENT, FY 2012 OCSE GRANT AWARDS (2012).

37. Child Support and Fatherhood Initiative in the Administration's FY 2014 Budget, OFFICE OF CHILD SUPPORT ENFORCEMENT (Apr. 13, 2013), http://www.acf.hhs.gov/programs/css/ resource/child-support-and-fatherhood-initiative-in-the-administrations-fy-2014, archived at http://perma.cc/A99E-GCQM [hereinafter Administration's FY 2014 Budget].

38. Id. 
parenting time provisions beginning in 2019. ${ }^{39}$ In September 2014, Congress adopted a Sense of the Congress resolution, which identifies the establishment of parenting time provisions within child support orders as "an important goal," and encourages states to use existing federal funds to establish and encourage such programs. ${ }^{40}$ In November 2014, the United States Department of Health and Human Services ("HHS") issued a proposed regulation that would permit stateinitiated child support orders to "recognize parenting time provisions pursuant to State child support guidelines or when both parents have agreed to the parenting time provisions." 41

Those advocating for these major policy changes posit that integrating child support and parenting time promotes increased engagement of fathers with their children. ${ }^{42}$ This, in turn, enhances fathers' willingness to comply with child support orders, strengthens the health and welfare of children, and promotes fairness by permitting parents to allocate financial and child rearing responsibilities in one proceeding. ${ }^{43}$

At first glance, the proposals seem to offer common sense measures to address some of the inequities that the segregation of child support matters from determinations of visitation and custody has engendered. ${ }^{44}$ Rather than having costly parallel proceedings, adjudicating parenting time in state-initiated child support cases ostensibly could provide a more efficient process that, on its face, resembles the integrated domestic relations approach frequently used to resolve family disputes upon divorce or following the separation of married parents. ${ }^{45}$ Such an integrated approach also appears to balance the playing field so that parents who are required to pay support are also assured an opportunity to spend time with their children. ${ }^{46}$ However, the proposals to require adjudication of parenting time in government initiated child support cases threaten to undermine the due process rights of both parents, impose an unjust burden on low-income families, weaken the quality of custody and visitation determinations, and immerse the federal government and state agencies in decisions that are more

39. Id.

40. Preventing Sex Trafficking and Strengthening Families Act, Pub. L. No. 113-183, § 303, 128 StAT. 1919, 1946 (2014) [hereinafter 2014 Congressional Resolution] ("States should use existing funding sources to support the establishment of parenting time arrangements, including child support incentives, Access and Visitation Grants, and Healthy Marriage Promotion and Responsible Fatherhood Grants.").

41. Flexibility, Efficiency, and Modernization in Child Support Enforcement Programs, 79 Fed. Reg. 221 at 68580 (proposed November 17, 2014) (to be codified at 45 CFR pt. 302) (emphasis added) [hereinafter HHS 2014 Notice of Proposed Rulemaking].

42. See supra notes $37,40,41$.

43. Id.

44. See Administration's FY 2014 Budget, supra note 37; HHS 2014 Notice of Proposed Rulemaking, supra note 41, at 68556; 2014 Congressional Resolution, supra note 40.

45. See infra Part II.A.

46. See infra Part II.A. 
appropriately left to parental discretion and impartial judicial officers. ${ }^{47}$ The proposals have the potential to deepen the state's involvement in the lives of lowincome families and reshape the nature of child custody and visitation proceedings. ${ }^{48}$

This Article proceeds in three parts to evaluate the merits of integrating custody and visitation determinations in government-initiated child support proceedings. Part I situates the federal parenting time proposals within the doctrines that shape the scope and allocation of parental rights and responsibilities. This part explores parents' ability to establish custody, visitation, and child support arrangements, both outside of the court system and within the context of domestic relations proceedings. The section goes on to explore the federal and state child support enforcement structure and recent attempts to change the goal of government involvement from recapturing costs to creating opportunities for parents to support and develop relationships with their children.

Part II explores the potential benefits of integrating child custody and visitation issues in child support proceedings. The section then analyzes the risks posed by proposals to mandate or incentivize integration as part of the state child support enforcement process. Part II posits that although it is important to offer integrated options to all parents, regardless of income, marital status, or port of entry for court filing, proposals to achieve integration through the state child support enforcement process undermine the fundamental rights of parents and inappropriately enmesh the government in the lives of low income families.

Finally, Part III proposes alternative mechanisms for encouraging parental access to children while protecting fundamental constitutional rights and ensuring quality custody and visitation determinations. It suggests that state courts and legislatures should develop integrated options for parents involved in state-initiated and non-state child support matters that: are voluntary; treat both parents as parties; explicitly address custody and visitation rights; incorporate procedural safeguards; offer clear legal information and assistance to ensure informed decision making; and utilize alternative dispute resolution ("ADR") mechanisms which offer families the opportunity to determine family arrangements in more non-adversarial settings. Although giving parents the option to address custody and visitation in child support cases is a worthy policy and court reform goal, it is not a strategy that necessarily will lead to greater child support compliance. Given the lack of rigorous empirical evidence demonstrating a causal link between visitation and child support compliance, the section ends by recommending that the federal Office of Child Support Enforcement and Congress prioritize and fund policies that directly incentivize financial support of children, including subsidized employment assistance, recognition of in-kind support, and child support assurance programs.

47. See infra Parts II and III.

48. Brito, supra note 13, at 235. 


\section{Allocating Parenting Responsibilities: Parental Access, CARETAKING, AND FINANCIAL SUPPORT OF CHILDREN}

\section{A. The Scope of Parents' Discretion to Allocate Their Rights and Responsibilities as Parents}

To contextualize how child support, child custody, and visitation remedies operate, it is useful to consider what they are meant to replace. A mother's legal relationship to her biological child typically is established automatically by virtue of the child's birth. ${ }^{49}$ The legal relationship of a father to a child may be established by marriage with the child's birth mother, adoption, or formal establishment of parentage through a voluntary acknowledgment or DNA testing. ${ }^{50}$

In the majority of states, legally recognized parents have coextensive parental rights and responsibilities by operation of law, regardless of their marital status and how they choose to structure their households. ${ }^{51}$ In these states both parents share rights to physical custody of the child, which includes the right to reside with and spend time with a child, and legal custody, which includes the right to make important decisions regarding the child ${ }^{52}$ Each parent also remains responsible for financially maintaining the child. ${ }^{53}$ These rights and

49. See, e.g., CAL. FAM. CODE $§ 7610$ (West 2014); D.C. CODE ANN. § 16-909 (2014); N.J. STAT. ANN. § 9:17-41 (2014).

50. See, e.g., ARK. Code ANN. § 9-10-108 (2014); D.C. CodE ANN. § 16-909 (2014); LA. Civ. Code ANN. art. 185 (2014); N.M. StAT. ANN. § 40-11A- 301, 302 (2010); 23 PA. Cons. STAT. ANN. § 5103 (2014) VA. CODE ANN. § 20-49.1 (2014). Some states also have set forth processes for establishing the parentage of non-biological mothers married to a child's biological mother. See, e.g., D.C. CODE $\S 16-909$ (2013). In other states, this process may present challenges. See generally Susan Appleton, Presuming Women: Revisiting the Presumption of Legitimacy in the Same-Sex Couples Era, 86 B.U. L. REV. 227 (2006).

51. See, e.g., ConN. GEN. StAT. AnN. § 45a-606 (West 2015) ("The father and mother of every minor child are joint guardians of the person of the minor, and the powers, rights and duties of the father and the mother in regard to the minor shall be equal"); ME. REV. STAT. tit. 19-A, § 1651 (2015) ("The father and mother are the joint natural guardians of their minor children and are jointly entitled to the care, custody, control, services and earnings of their children. Neither parent has any rights paramount to the rights of the other with reference to any matter affecting their children”); TEX. FAM. CODE ANN. § 151.001 (West 2007). See also Deville v. Lagrange, 388 So.2d 696, 698 (La. 1980) ("Parenthood itself confers a right to custody"); sources cited supra note 6. But see Clare Huntington, Postmarital Family Law: A Legal Structure for Nonmarital Families, 67 STAN. L. REV. 167, 203-205 (2015) (noting that the majority of states do not have a default rule for allocating custody between parents when the parents are unmarried but arguing that the entitlement of both parents to a relationship with a child is distinct from physical or legal custody).

52. Homer H. Clark, JR., THE LAW OF DOMESTIC RELATIONS IN THE United STATES 481 (2d ed. 1987); Linda D. Elrod, Child Custody Practice and Procedure $\S \S 4.1,4.34$ (2013).

53. See e.g., CAL. FAM. CODE $§ 3900$ (West 2014); N.C. GEN. STAT. § 50-13.4 (2014); N.Y. FAM. LAW $§ 413$ (McKinney 2014); 23 Pa. CONS. Stat. AnN. § 4321 (West 2014); TeX. FaM. 
responsibilities attach automatically by operation of law to legally recognized parents; parents do not need to obtain a court order to exercise authority over their children. ${ }^{54}$ Approximately fifteen states differentiate between married and unmarried parents, establishing that an unmarried mother has sole custody of a child at birth and an unmarried father must seek court intervention to establish his rights to custody and visitation. ${ }^{55}$

When parents live together they jointly, at least in theory, share responsibility for meeting children's needs through financial support, emotional support, and physical caretaking. ${ }^{56}$ A division of labor results and parents make trade-offs; for example, one parent may work longer hours to bring in more financial support, requiring the other to devote more time to physical care, while both may provide emotional support. Whether parents live under one roof or live separate lives, absent evidence of abuse and neglect, the law in most states permits parents to allocate parenting responsibilities and obligations as they see fit. ${ }^{57}$

If parents cannot agree on how to allocate caretaking responsibilities or financial resources to meet a child's needs, parents can seek court intervention. State statutes and common law require courts to use overarching principles, such as the best interest of the child, to determine how to allocate these rights and duties. ${ }^{58}$ The statutes and common law that govern the establishment and

CODE ANN. § 151.001 (West 2014).

54. See supra notes 6, 51, 52; see also Troxel v. Granville, 530 U.S.57 65-66 (2000) (parents have a fundamental liberty interest in making decisions regarding the care, custody, and control of their children).

55. Huntington, supra note 51, at 204-05, n.204. Some states appear to have conflicting laws on this point. Compare S.C. CODE ANN. § 63-17-20 (2014) ("Unless the court orders otherwise, the custody of an illegitimate child is solely in the natural mother unless the mother has relinquished her rights to the child. If paternity has been acknowledged or adjudicated, the father may petition the court for rights of visitation or custody in a proceeding before the court apart from an action to establish paternity"), with S.C. CODE ANN. § 63-5-30 (2014) ("The mother and father are the joint natural guardians of their minor children and are equally charged with the welfare and education of their minor children and the care and management of the estates of their minor children; and the mother and father have equal power, rights, and duties, and neither parent has any right paramount to the right of the other concerning the custody of the minor or the control of the services or the earnings of the minor or any other matter affecting the minor").

56. See Yerkes v. Yerkes, 824 A.2d 1169, 1171 (Pa. 2003) (quoting Conway v. Dana, 318 A.2d 324, 326 (Pa. 1974)); see also Nkopchieu v. Minlend, 718 S.E.2d 470, 476 (Va. Ct. App. 2011) (quoting Kelley v. Kelley, 449 S.E.2d 55, 56 (Va. 1994)).

57. See supra note 54.

58. See, e.g., D.C. Code ANN. 16-914 (2014); NEB. REV. StAT § 43-2935(1) (2014); N.H. ReV. StAT. ANN. § 461-A:6(1) (2014); N.D. Cent. Code AnN. § 14-09-30(1) (West 2014); Оhio Rev. Code ANN. § 3109.04 (West 2014); TENN. CodE ANN. § 36-6-403(2) (West 2014); see also Alaska Stat. ANN. § 25.24.150 (West 2014); 750 Ill. Comp. Stat. 5/602 (2014); La. Civ. Code ANN. art. 131 (2014); MiCH. COMP. LAWS $\$ 722.25$ (2014); NEB. REV. STAT. § 42-364 (2014); N.Y. Dom. Rel. LAW $§ 70$ (McKinney 2014); N.D. Cent. Code ANN. § 14-09-29 (West 2014); VA. 
modification of child custody and visitation are generally separate from the statutes and court rules that govern the calculation, distribution, and enforcement of child support. ${ }^{59}$ Although governed by distinct laws, child custody and child support are interrelated in several important ways. ${ }^{60}$ For example, a parent's ability to spend time with a child may be impacted by the parent's employment circumstances or the priority that parent places on financial caretaking versus physical or emotional caretaking. Similarly, the financial costs a parent incurs when caring for a child increase in accordance with the amount of time the child spends with that parent. ${ }^{61}$ State child support guidelines (codified in statutes or court rules) often recognize the interconnected nature of child custody and child support issues by considering the amount of time a child spends with each parent when calculating the amount of support owed. ${ }^{62}$

By invoking the jurisdiction of state courts to address matters of child custody and child support, a parent authorizes the judiciary to exercise its parens patriae role as protector of children and cedes control over the allocation of parenting rights and responsibilities to the state. ${ }^{63}$ In domestic relations or dissolution proceedings ${ }^{64}$ involving married couples who are divorcing or separating, courts often address issues of custody, visitation, and child support

CODE ANN. § 20-124.3 (West 2014); WIS. STAT. § 767.41 (2014).

59. See Jane C. Venohr, Child Support Guidelines and Guidelines Reviews: State Differences and Common Issues, 47 FAM. L.Q. 327, 342 (2013); see also Linda D. Elrod \& Milfred D. Dale, Paradigm Shifts and Pendulum Swings in Child Custody: The Interests of Children in the Balance, 42 FAM. L.Q. 381, 410 (2008). Like many components of state child support enforcement systems, the adoption of state child support guidelines to standardize the calculation of child support obligations was required by the federal government as a condition of federal TANF funding. 42 U.S.C. $\S 666$ (2014).

60. See Chauncey Brummer \& Janet A. Flaccus, Modification of Child Custody and Child Support: UCCJEA and UIFSA Collide, 2000 ARK. L. NOTES 15, 18 (2000) ("The fact that there is court concern for the commingling of substantive issues of child support and child custody acknowledges the fact that these issues are often ... interrelated.").

61. See Jane C. Venohr \& Robert G. Williams, The Implementation and Periodic Review of State Child Support Guidelines, 33 FAM. L.Q. 7, 21 (1999).

62. Venohr, supra note 59, at 341; Venohr \& Williams, supra note 61, at 21-23; see, e.g., Colo. Rev. StAT. ANN. § 14-10-115 (West 2014); D.C. CoDE ANN. § 16-916.01 (2014).

63. See Santosky v. Kramer, 455 U.S. 745, 766 (1982) ("two state interests are at stake in parental rights termination proceedings - a parens patriae interest in preserving and promoting the welfare of the child ..."); see also Aaron E. Zurek, All the King's Horses and All the King's Men: The American Family After Troxel, the Parens Patriae of the State, A Mere Eggshell Against the Fundamental Right of Parents to Arbitrate Custody Disputes, 27 HAMLINE J. PUB. L. \& POL'Y 357, 377-83 (2006) (discussing the development of parens patriae).

64. "Domestic relations" refers to the body of law dealing with marriage, divorce, adoption, child custody and support, child abuse and neglect, paternity, and juvenile delinquency. See BLACK'S LAW DiCTIONARY (9th ed. 2009) (defining family law). "Dissolution" refers specifically to the severance of legal ties between a married couple. See id. (defining divorce). 
in one proceeding. ${ }^{65}$ This holistic approach evolved from the historical practice of treating child custody as a subset of property rights during a marriage dissolution court proceeding. ${ }^{66}$ Some states require this type of integration, ${ }^{67}$ whereas other states give parents the option to raise issues of custody or child support in divorce proceedings but do not necessarily require them to do so. ${ }^{68}$

Unmarried parents also may petition the court to address multiple family law issues in one proceeding. ${ }^{69}$ These issues can include establishment of paternity, custody, visitation, and child support. ${ }^{70}$ The proceedings generally take place in

65. Elrod \& Dale, supra note 59, at 410.

66. J. Herbie DiFonzo, From the Rule of One to Shared Parenting: Custody Presumptions in Law and Policy, 52 FAM. CT. REV. 213, 214 (2014).

67. See, e.g., 750 ILL. CoMP. StAT. 5/601 (2014); N.Y. DoM. Rel. § 240 (McKinney 2014); OHIO Rev. Code ANN. § 3105.21 (2014); Wis. StAt. ANN. § 767.41 (2014). See also Engemann v. Engemann, 219 N.W.2d 777, 780 (Mich. Ct. App. 1974) ("Where a trial court has jurisdiction to grant a divorce, it is mandatory that the court dispose of any related matters concerning spousal support, child support, and property”); Rich v. Rich, 871 S.W.2d 618, 624 (Mo. Ct. App. 1994) ("In Missouri, it is mandatory for a trial court in a dissolution case, where it has jurisdiction to do so, to provide for the custody of a minor dependent child of the parties.").

68. See, e.g., Alaska Stat. § 25.24.150 (2014); ConN. GEN. Stat. AnN. § 46b-56 (2014) ("at any time after the return day of any complaint under section 46b-45, the court may make or modify any proper order regarding the custody, care, education, visitation and support of the children if it has jurisdiction") (emphasis added); D.C. CODE ANN. § 16-914 (1)(A)(2014) ("In any proceeding between parents in which the custody of a child is raised as an issue, the best interest of the child shall be the primary consideration") (emphasis added); MASS. GEN. LAWS ch. 208, § 28 (2014); Miss. CODE ANN. § 93-5-23 (2014); N.J. STAT. ANN. § 2A:34-23 (West 2014); OR. REV. StAT. § 107.105 (2014); W. VA. CODE ANN. § 48-5-603 (2014). See also Strohmeyer v. Strohmeyer, 439 A.2d 367, 369 (Conn. 1981) (affirming the power of the court to consider and rule upon matters of custody in divorce cases where the parties choose not to bring custody issues before the court). In several states, once a court determines a divorce action that does not address custody, the court may maintain jurisdiction to decide child custody and support at a later date. See, e.g., Roble v. Roble, 295 S.W.2d 817, 818 (Tenn. App. 1956); see generally CLARK, supra note 2, at 791; Miss. Divorce, Alimony \& Child Custody § 14:6 (2014); 19 Tenn. Prac. Tenn. Divorce, Alimony \& CHILD CUSTODY $§ 22: 7$ (2d ed. 2014); George Blum et. al., Jurisdiction of Court to Award Custody After Final Judgment of Divorce, 24A AM. JuR. 2D DivORCE AND SEPARATION § 866 (2015); M.L. Cross, Opening or Modification of Divorce Decree as to Custody or Support of Child not Provided for in the Decree, 71 A.L.R.2d 1370 (1960).

69. See, e.g., In re G.J.A., 331 P.3d 835, 837 (Mont. 2014) (Unmarried father filed a petition for a parenting plan to determine custody as well as for child support); In re ARF, 307 P.3d 852, 854 (Wyo. 2013) (Unmarried father filed action seeking establishment of paternity, custody and child support and trial court awarded custody to the mother, visitation to the father and child support to the mother); Hebert v. Schexnayder, 113 So. 3d 1097, 1099 (La. Ct. App. 2013) (Unmarried mother filed for establishment of paternity, joint custody and child support); Jeffers v. McLeary, 118 So. 3d 287 (Fla. Dist. Ct. App. 2013) (Trial court addressed both child support and custody (time sharing) in case involving unmarried parents).

70. Id. 
the family or domestic relations branch of the trial court. ${ }^{71}$

Whether raised as part of a divorce case or within a separate custody filing, courts frequently refer or mandate parties to participate in mediation to resolve issues related to children. ${ }^{72}$ Mediation offers parents the opportunity to negotiate agreements regarding custody, visitation, and/or support, which may be incorporated or merged into a court order. ${ }^{73}$ The authority courts have to alter custody agreements reached by parties varies by state. ${ }^{74}$ In some states, parents have broad discretion to fashion caretaking and financial arrangements and courts are required to give considerable deference to such agreements. ${ }^{75}$ Other states require greater scrutiny of parental agreements to ensure that they serve children's best interests. ${ }^{76}$

One significant difference between custody cases involving married and unmarried parents is that by operation of law, married parents are assumed to be the parents of any children born during the marriage and therefore are presumed to have defacto custody while married and entitled to seek formal custody of those children after separation. ${ }^{77}$ By contrast, unmarried fathers and nonbiological mothers must establish parentage and legitimize their parental status

71. Elrod \& Dale, supra note 59 , at 410 .

72. See generally Jane C. Murphy, Revitalizing the Adversary System in Family Law, 78 U. CIN. L. ReV. 891, 911-14 (2010); see CARrie MENKEL-MEAdOW ET AL., Dispute Resolution: BEyOND THE ADVERSARIAL MODEL 407-09 (1st ed. 2005).

73. See, e.g., NEB. REV. STAT. § 42-364 (1)(a) (2014) ("In an action under Chapter 42 involving child support, child custody, parenting time, visitation, or other access, the parties and their counsel, if represented, shall develop a parenting plan as provided in the Parenting Act. If the parties and counsel do not develop a parenting plan ... the case shall be referred to mediation or specialized alternative dispute resolution as provided in the Parenting Act"); N.C. GEN. STAT. Ann. $\S 50-13.1$ (b) (West 2013) ("Whenever it appears to the court, from the pleadings or otherwise, that an action involves a contested issue as to the custody or visitation of a minor child, the matter, where there is a program established pursuant to G.S. 7A-494, shall be set for mediation of the unresolved issues as to custody and visitation. . . . Alimony, child support, and other economic issues may not be referred for mediation pursuant to this section.).

74. Linda Jellum, Parents Know Best: Revising Our Approach to Parental Custody Agreements, 65 OHIO ST. L.J. 615, 618 (2004); see, e.g., D.C. CODE ANN. 16-914 (2014) (permitting courts to reject or change parental agreements regarding custody only if there is clear and convincing evidence that such agreement is not in the best interests of the child); see also E. Gary Spitko, Reclaiming the "Creatures of the State': Contracting for Child Custody Decisionmaking in the Best Interests of the Family, 57 WASH. \& LEE L. REV. 1139, 1212 (2000).

75. Jellum, supra note 74, at 618; see, e.g., D.C. CoDE ANN. 16-914 (2014); see also Spitko, supra note 74 , at 1212.

76. Jellum, supra note 74, at 623.

77. See Huntington, supra note 51, at 178; see also David D. Meyer, Parenthood in a Time of Transition: Tensions Between Legal, Biological, and Social Conceptions of Parenthood, 54 AM. J. COMP. L. 125, 127 (2006) (describing the history of marital presumption that presumed parental connection between married spouses and children produced during the marriage). 
before pursuing custody or visitation rights in court. ${ }^{78}$ Many states have established separate courts or administrative agency proceedings to deal with parentage and support issues. ${ }^{79}$ This bifurcation of proceedings has accelerated with the proliferation of cases initiated by state child support agencies. ${ }^{80}$ These state agencies bring cases on behalf of two categories of parents: i) low-income parents who receive benefits through the Temporary Assistance for Needy Families cash benefits program and have assigned their right to collect support to the state and ii) parents who formerly received or never received TANF but seek child support services from the states. ${ }^{81}$ Unlike divorce and custody proceedings, which typically permit or require parents to address issues of custody and child support together, proceedings in child support courts or administrative tribunals generally do not permit parents to address issues of custody or visitation. ${ }^{82}$ Parents who desire adjudication of child custody and visitation must pursue separate proceedings in a different forum. ${ }^{83}$

\section{B. The Evolving Mission of the State Child Support Enforcement System}

In recent decades, as federal welfare policy has shifted to emphasize child support rather than public assistance as a primary source of financial support for low-income families, ${ }^{84}$ the reach and influence of state child support enforcement agencies upon families in the United States has dramatically expanded. Today, state child support agencies serve approximately 17 million children and their parents. ${ }^{85}$

Initially, the primary goals of state involvement in parentage and child support matters included recapturing costs expended by the state on public

78. Id.; Bernardo Cuadra, Family Law-Maternal and Joint Custody Presumptions for Unmarried Parents: Constitutional and Policy Considerations in Massachusetts and Beyond, 32 W. NEW ENG. L. REV. 599, 619-20 (2010).

79. See, e.g., OR. Rev. StAT. AnN. § 416.419 (2)(a) (West 2015) ("When a hearing is requested pursuant to ORS 416.427, the tribunal is the Office of Administrative Hearings, except as provided in ORS 416.430 (b). When an order is appealed pursuant to ORS 416.427 (6), the tribunal is a circuit court.") See also Huntington, supra note 51, at 183.

80. Id.

81. Turetsky, supra note 26, at 403; see also SOLOMON-FEARS, supra note 18, at 4-5.

82. See Huntington, supra note 51, at 183-84.

83. NAT'L Child SupPort Enforcement Ass'n, PAREnting Time Orders, (2013), available at $\mathrm{http}: / /$ www.ncsea.org/documents/Parenting-Time-Order_7.31.13.pdf, archived at http://perma.cc/D2T2-NGGB [hereinafter PARENTING TIME ORDERS].

84. See 42 U.S.C. $\S \S 604,651,656$ (2014).

85. OCSE Fact Sheet, supra note 31 (state child support agencies assisted 16.9 million children in FY 2013); see also Turetsky, supra note 26, at 403 (citing Linda Mellgren et al., Characteristics of Families Using Title IV-D Services in 2001, Office of the Assistant Secretary for Planning and Evaluation, U.S. Dep't of Health and Human Servs., http://aspe.hhs.gov/ hsp/CSEChar04/index.htm (last visited May 6, 2015), archived at http://perma.cc/K4XA-AHEM (Approximately sixty percent of all child support-eligible families utilize IV-D agency services)). 
assistance benefits and preventing parents from becoming dependent on public benefits at some point in the future. ${ }^{86}$ Section IV-D of the Social Security Act ("Section IV-D") $)^{87}$ required parents who received cash welfare benefits to assign their rights to collect child support to the state. ${ }^{88}$ The law aimed to compel noncustodial parents to comply with their legal obligations to financially support their children and replenish state dollars expended on children. ${ }^{89}$ The Personal Responsibility and Work Opportunity Reconciliation Act ("PRWORA") of 1996 ramped up these efforts by requiring states to maintain robust child support enforcement programs. ${ }^{90}$

Federally funded programs also expanded to extend state child support services at very low cost to parents who formerly received TANF or never received TANF. ${ }^{91}$ This expansion aimed to increase the financial resources of low to moderate income families and decrease the number of families who otherwise might resort to cash welfare benefits. ${ }^{92}$

This focus on cost recapture has shaped the relationships of parents to one another and altered the ability of low-income parents to allocate shared parenting responsibilities. ${ }^{93}$ Section IV-D and PRWORA compel the lowest income families to submit at least some of their parental decision-making (regarding how parents will share and reimburse one another for financial support for a child and provide medical insurance) to government intervention via child support proceedings. ${ }^{94}$ Parents who need TANF benefits give up the opportunity to work out financial support arrangements informally between themselves and instead must cooperate with state efforts to establish parentage and collect support. ${ }^{95}$ The processes for establishing child support orders vary widely among states, from litigation oriented, court-based processes like that in the District of Columbia to largely administrative processes like those in Pennsylvania. ${ }^{96}$

86. 45 C.F.R. $\S \S 302.32,302.51$ (2014); see also Turetsky, supra note 26, at 402. Janelle T. Calhoun, Interstate Child Support Enforcement System: Juggernaut of Bureaucracy, 46 MERCER L. REV. 921,930 (1995).

87. Because they originate from this section of the Social Security Act, state child support enforcement agencies often are called "IV-D agencies." Social Security Act, 42 U.S.C. $§ \S 651-$ $669 \mathrm{~b}$ (2014) (Title IV-D).

88. 42 U.S.C. $§ 656$ (2014).

89. Id. $\S 651$.

90. See generally id. $\S \S 651-669 \mathrm{~b}$.

91. See CHILD SUPPORT HANDBOOK, supra note 36, at 8-9.

92. Id.; see also Turetsky, supra note 26, at 410.

93. See Daniel L. Hatcher, Child Support Harming Children: Subordinating the Best Interests of Children to the Fiscal Interests of the State, 42 WAKE FOREST L. REV. 1029, 1066-70 (2007) (discussing the beneficial and detrimental effects of allowing states to recapture costs).

94. See generally 42 U.S.C. § 659 (2014); see also Wimberly, supra note 28, at 736.

95. 42 U.S.C. $\S 608$ (2014).

96. Court Support Process: Administrative v. Judicial, NAT'L CONFERENCE OF STATE LEGISLATURES (Apr. 2013), http://www.ncsl.org/research/human-services/child-support-processadministrative-vs-judicial.aspx, archived at http://perma.cc/HLT8-X88Z. 
Whatever the process, the outcome of state-initiated child support proceedings is the same: the parents' financial support obligation is governed by a legally binding and enforceable order that directs one parent to pay his or her share of a child's financial support to the state or to the child's other parent (or caretaker), and generally also determines how medical coverage will be provided to the child[ren]. ${ }^{97}$

In many states, only the parent alleged to owe support is considered a party to a child support proceeding initiated by the state child support agency. ${ }^{98}$ In such jurisdictions, the state is the initiating party and the custodial parent to whom support is owed is not considered a party to the action unless she formally intervenes in or joins the action. ${ }^{99}$ This is true even though the interests of the state child support agency and the custodial parent may differ and, in some cases, directly conflict. ${ }^{100}$ Instead, the custodial parent is considered a witness and may not be entitled to formal notice or an opportunity to be heard in the case. ${ }^{101}$

Until recently, state child support agencies have not handled custody or visitation matters. ${ }^{102}$ These have been considered private matters between the

97. See, e.g., 28 U.S.C. § 1738B (2014); IDAHO CODE ANN. § 7-1402 (West 2014); IND. Code ANN. § 31-18-1-3 (West 2014); N.C. GEN. StAT. ANN. § 52C-1-101 (West 2014); OHIO REV. Code Ann. § 3119.01(B)(2) (West 2014). See, e.g., OhIo Rev. CodE AnN. § 3119.30(A) (West 2007) ("In any action or proceeding in which a child support order is issued or modified, the court, with respect to court child support orders, and the child support enforcement agency, with respect to administrative child support orders, shall determine the person or persons responsible for the health care of the children subject to the child support order and shall include provisions for the health care of the children in the child support order."). Additionally, states have the option to provide a "pass through" amount to TANF families whereby the state transfers a certain amount of any child support collected (amount varies by state) directly to the TANF family without any resulting reduction in TANF benefits. See, e.g., \$150 Pass Through, D.C. ChILD SupPORT SERVs. DIV., http://cssd.dc.gov/page/150-pass-through (last visited Dec. 28, 2014), archived at http://perma.cc/P8XH-V5YG. The District of Columbia, for example, allows up to $\$ 150$ to be passed through. Id.

98. Stacy Brustin, More Than a Witness: The Role of Custodial Parents in the IV-D Child Support Process, 26 CHILDREN's LEGAL RigHTS J. 37, 43-44 (2006).

99. Id. at 44 (giving examples of various jurisdictions' positions on a custodial parent's status as a party in a child support matter).

100. Id. at 41-43; see also Paula Roberts, Child-Support Issues for Parents Who Receive Means-Tested Public Assistance, 34 CLEARINGHOUSE REV. 182, 187-88 (2000) (providing situations in which the interests conflict).

101. Brustin, supra note 98, at 44-46.

102. For instance, California, Florida, New York, South Carolina, Tennessee, and Washington do not offer visitation or custody services. See, e.g., CAL. DEP'T OF CHILD SUPPORT SERVS., CHILD SUPPORT HANDBOOK 6 (2014), available at https:/www.childsup.ca.gov/ LinkClick.aspx?fileticket $=$ Mq0dvG7KgQQ\%3D\&tabid=85\&mid=974, archived at http://perma.cc/5NPD-MT4U; Frequently Asked Questions for Child Support Enforcement Division, ELEVEnTH JUdicial CiRCUIT OF FlA., http://www.jud11.flcourts.org/scsingle.aspx? pid=311\#ceq15 (last visited Aug. 14, 2014), archived at http://perma.cc/K5ZF-XT2X; 
parents and outside the purview of state interest. ${ }^{103}$ However, OCSE, as the agency responsible for setting the mission and strategic goals for the state child support agencies that receive federal funding, ${ }^{104}$ has begun to promote a shift in the program's mission; moving from a goal of cost recapture to a focus on facilitating the ability of noncustodial parents to support children. ${ }^{105}$

The number of TANF recipients has dropped dramatically over the past two decades. ${ }^{106}$ This decline is attributable to PRWORA's establishment of stringent time limits for receipt of TANF and more limited funding available for TANF recipients in many states. ${ }^{107}$ As of 2010, only fourteen percent of the entire IV-D caseload consisted of TANF recipients. ${ }^{108}$ Increasingly, state child support agencies are assisting families who have never received TANF, who formerly received TANF, or who will only receive TANF for a limited period of time. ${ }^{109}$

Noncustodial Parent Information, N.Y. OfFICE OF TEMP. AND DisABILITY Assistance, https://www.childsupport.ny.gov/dcse/non_custodial_parent_info.html(last visited Aug. 14, 2014), archived at http://perma.cc/LWA8-BWNQ; TENNESSEE DEP'T OF HuMAN SERVS., TENNESSEE CHILD SUPPORT HANDBOOK 4 (2013), available at https:/www.tn.gov/humanserv/cs/ cs_handbook.pdf, archived at http://perma.cc/5XG4-7F5F.

103. CAL. DEP'T OF ChILD SuPPORT SERVS., supra note 102, at 6; Frequently Asked Questions for Child Support Enforcement Division, supra note 102; Noncustodial Parent Information, supra note 102; TENNESSEE DEP'T OF HUMAN SERVS., supra note 102, at 4; but see Jessica Pearson et al., A New Look at an Old Issue: An Evaluation of the State Access and Visitation Grant Program, 43 FAM. CT. REV. 372, 372 (2005) (“[S]tate child support agencies are playing a more active role in trying to address the practical relationship between visitation and child support payment ....").

104. OCSE Fact Sheet, supra note 31.

105. See OfFice of Child Support ENFORCEMEnt, NATIONAl ChILd Support StrategiC PLAN FY 2010-2014 5-6 (2013), available at http://www.acf.hhs.gov/programs/css/resource/ national-child-support-strategic-plan-fy-2010-2014, archived at http://perma.cc/6E7R-2BT5; see also OCSE FACT SHEET, supra note 31.

106. In 1991, there was an average of over 12 million monthly recipients of TANF. DEP'T OF Health and Human Servs., Indicators of Welfare Dependence: Annual Report to CONGRESS app. A-9 (2003), available at http://www.aspe.hhs.gov/HSP/indicators03/index.htm, archived at http://perma.cc/A7AQ-SVGJ. In 2001, the monthly average dramatically decreased to 5.4 million recipients. $I d$. In 2011 , the average decreased further to only about 4.4 million monthly recipients. TANF: Total Number of Recipients, DEP'T OF HEALTH AND HuMAN SERVs. (Apr. 3, 2012), http://www.acf.hhs.gov/programs/ofa/resource/2011-recipient-tan, archived at http://perma.cc/Q9DX-BC5V; see also Turetsky, supra note 26, at 403-04.

107. Personal Responsibility and Work Opportunity Reconciliation Act, Pub. L. No. 104-193, 110 Stat. 2105 (1996) (codified in scattered sections of 42 U.S.C.).

108. Child Support Enforcement Introduction and Overview, U.S. HousE OF REPRESENTATIVES (Aug. 9 2012), http://greenbook.waysandmeans.house.gov/2012-green-book/ child-support-enforcement-cover-page/introduction-and-overview, archived at http://perma.cc/ JYV5-JRLM.

109. Vicki Turetsky \& Andrea Watson, Center for Law and Social Policy, Child SUPPORT CASELOADDATA: RECENT TRENDS iii (1998) ("Over the years, the composition of the IV$\mathrm{D}$ caseload has changed significantly. This is because the non-welfare caseload has grown much 
The original cost recapture mission of the child support collection apparatus is becoming obsolete as states have, at most, a minimal pecuniary interest in collecting reimbursement for receipt of time-limited TANF or for TANF arrears. ${ }^{110}$

As a result of these shifting realities, OSCE has encouraged state agencies to move from a punitive enforcement approach to an approach that focuses on setting realistic child support orders, encouraging engaged fatherhood, and facilitating access to children. ${ }^{111}$ To this end, state child support agencies have begun to offer services to families such as job training and parenting education. ${ }^{112}$ PRWORA encouraged this increased focus on parental involvement, specifically noncustodial fathers' involvement with their children. ${ }^{113}$ The legislation authorized increased funding for fathering programs, grounded on the premise that fathers who are more involved in parenting pay higher amounts of child support. ${ }^{114}$ This funding enabled state child support agencies to develop programs to facilitate increased access of noncustodial parents to children through "parenting time" agreements. These programs use the terminology "parenting time" rather than "visitation" to soften the potentially negative suggestion that one parent merely "visits" with his or her own child. ${ }^{115}$ Whether

faster than the welfare caseload.").

110. See id.

111. See OSCE Strategic Plan, supra note 31, at 9-10; see also OFFICE OF CHILD SUPPORT ENFORCEMENT, DEP'T OF HEALTH AND HuMAN SERVS., NONCUSTODIAL PARENTS: SUMMARIES OF RESEARCH, GRANTS AND PRACTICES 6 (2009), available at http://www.acf.hhs.gov/sites/default/ files/ocse/dcl_09_26a.pdf, archived at https://perma.cc/WCZ5-VPGM?type=pdf [hereinafter NonCUSTODIAL PARENTS] (funding the Partners for Fragile Fathers program which sought to encourage positive relationships between unmarried fathers and their children).

112. See Office of Child Support Enforcement, Dep'T of Health and Human Servs. Work-Oriented Programs With ACTIVE CHILD SUPPORT AGENCY InVOLVEMENT THAT SERVES Noncustodial Parents 1 (2014) ("As of February 2014, at least 30 states and the District of Columbia have work-oriented programs with active child support agency involvement ....”).

113. 42 U.S.C. $\S 603(a)(2)(C)(2014)$.

114. Congress authorized the State Access and Visitation Program in 1996. This program awarded annual grants of $\$ 10$ million per year to states engaged in access and visitation programs. PARENTING TIME ORDERS, supra note 83 , at 1 . Several studies have demonstrated an association between child support and visitation, but these studies have not actually determined whether there is a causal link between the two. See generally Lenna Nepomnyaschy \& Irwin Garfinkel, Child Support Enforcement and Fathers' Contributions to Their Nonmarital Children, 84 SoC. SERV. REV. 341 (2010). Research more clearly points to the connection between parental access and other positive outcomes for children such as stronger educational performance and decreased negative behavior. Solangel Maldonado, Deadbeat or Deadbroke: Redefining Child Support for Poor Fathers, 39 U.C. DAVIS L. REV. 991, 997-98 n.24-29 (2006) (citing numerous studies on the benefits of fathers involvement with their children).

115. Mark D. Brent, Current Trends in Dissolution of Marriage, Child Custody Litigation, and Mediation of Dissolution Actions in Illinois, STRATEGIES FOR FAMILY LAW IN ILLINOIS 3 (Falls ed., Aspatore 2010) ("“Parenting time' should be the preferred term. Because there are more cases 
increased access actually leads to enhanced child support compliance is the subject of continued research and debate. ${ }^{116}$

Researchers have conducted studies to assess the impact of visitation on child support payment and the relationship between the amount of child support ordered and the consistency of payment. ${ }^{117}$ They have analyzed, for example, longitudinal data to assess whether the involvement of noncustodial fathers with their children through formal child support (via court order), informal child support (direct cash payments), in-kind support, or direct time spent with the children decreased the number of hardships faced in mothers' households. ${ }^{118}$ Although several initial studies found that expanded visitation leads to increased payment of cash or in-kind support and that such payments can help bring families out of poverty and reduce material and financial hardship, others have suggested that additional studies are needed to identify whether factors such as fathers' involvement with children leads to more financial support. ${ }^{119}$ Recent studies demonstrate that the picture is complex and levels of involvement may depend more significantly on factors such as the quality of the relationship between the parents prior to their separation and the status of parents' new relationships. ${ }^{120}$ In addition, assessments of whether access and visitation

where both parents have been active 'hands-on' caregivers ...."). This shift in terminology mirrors changes adopted by states such as Ohio, Tennessee, and Colorado that have abandoned the terms "custody" and "visitation" and substituted "parenting responsibilities" or "parental responsibilities" to denote custody and decision-making as well as the phrase "parenting time" to denote visitation. OHio Rev. CodE ANN. § 3109.04 (West 2014); TENN. CODE ANN. § 36-6-402 (West 2014); see generally COLO. REV. STAT. ANN. $§ 14-10$ to -13.7 (West 2014).

116. The National Child Support Enforcement Association has suggested that in such programs, "helping parents to establish parenting-time orders and addressing their parenting-time plans is associated with improved patterns of child support payment." Id. (discussing OCSE funded demonstration projects and describing the use of facilitators in San Diego, California to help the development of voluntary parenting plans, which address physical residence of the child, decisionmaking, and time spent with parents); but see Chien-Chung Huang, Mothers' Reports of Nonresident Fathers' Involvement with Their Children: Revisiting the Relationship Between Child Support Payment and Visitation, 58 FAM. REL. 54, 58-60 (2009) (there are not adequate findings that increasing the noncustodial parent's visitation will increase the amount of child support paid).

117. See, e.g., Lenna Nepomnyaschy \& Irwin Garfinkel, Fathers' Involvement with Their Nonresident Children and Material Hardship, 85 SOC. SERV. REV. 3, 3-4 (2011), available at http://crcw.princeton.edu/workingpapers/WP10-12-FF.pdf, archived at http://perma.cc/97QKP2AW.

118. Id. at 32 .

119. Id. at 3; see also Nepomnyaschy \& Garfinkel, supra note 114, at 370-71 (suggesting that government child support enforcement efforts increases the amount of formal support received by families, but decreases the amount of informal support provided, resulting in a net neutral impact on the overall amount of support that unmarried mothers received).

120. Claire M. Kamp Dush et al., Predictors of Supportive Coparenting After Relationship Dissolution Among At-Risk Parents, 25 J. FAM. PSYCHOL. 356, 356 (2011), available at http://www.ncbi.nlm.nih.gov/pmc/articles/PMC3148851/?report=reader, archived at 
programs actually have increased noncustodial parents' access to and time spent with their children are mixed. ${ }^{121}$

The Obama administration has taken a number of steps to expand the scope of state child enforcement programs to include "parenting time."122 In October 2013, OCSE published a clarification of its mission to specify that it encompasses the establishment of parenting time arrangements. ${ }^{123}$ President Obama's recent budgets included a "Child Support and Fatherhood Initiative," which would impose a new condition on states that accept federal TANF funds. ${ }^{124}$ The initiative would require state child support agencies to address "parenting time responsibilities" in all new child support orders sought by the state by $2019 .{ }^{125}$

HHS issued a similar proposed regulation in November 2014, which likewise would revise the conditions imposed on states that accept federal funding to permit state child support agencies to include parenting time provisions in the child support orders they establish. ${ }^{126}$ Specifically, the proposed rule would allow state-initiated child support orders to "recognize parenting time provisions pursuant to State child support guidelines or when both parents have agreed to the parenting time provisions." 127 The agency clarified that the "pursuant to State child support guidelines" language is intended to encompass state child support guidelines that "incorporate allowances or credits for the amount of time children spend with both parents in the calculation of the child support order amount." 128 State child support guidelines in more than thirty states contain such provisions. ${ }^{129}$

http://perma.cc/ZA6F-WHH7 ("Overall, the relationship characteristics of parents were important predictors of supportive coparenting both initially and over time"); see also Laurie S. Kohn, Engaging Men as Fathers: The Courts, the Law and Father-Absence in Low Income Families, 35 CARDOZO L. REV. 511, 521 (2013).

121. OfFice of ChILd Support EnForcement, Dep'T of HEAlth ANd Human SERVS., Child ACCESS AND Visitation Programs: PARTicipant Outcomes 50-54 (2006), available at http://www.acf.hhs.gov/sites/default/files/ocse/dcl_07_15a.pdf, archived at http://perma.cc/635RZ4WD [hereinafter VISITATION PROGRAMS].

122. See PARENTing Time Orders, supra note 83 , at 1.

123. See Statement of Organization, Functions, and Delegations of Authority, 78 Fed. Reg. 60880-60883 (Oct. 2 2013); see also OFFICE OF CHILD SUPPORT ENFORCEMENT, DEP'T OF HEALTH \& HUMAN SERVS., DisCRETIONARY GRANTS FOR PARENTING TIME OPPORTUNITIES FOR CHILDREN IN THE CHILD SUPPORT PROGRAM (2013), available at http://www.acf.hhs.gov/sites/default/files/ programs/css/14_discretionary_grants_for_ptoc_final.pdf, archived at $\mathrm{http} / / / \mathrm{perma} . \mathrm{cc} / \mathrm{S} 449-\mathrm{K} 9 \mathrm{LZ}$.

124. See Administration's FY 2014 Budget, supra note 37.

125. Id.

126. HHS 2014 Notice of Proposed Rulemaking, supra note 41, at 68580.

127. Id.

128. Id. at 68556. Therefore, the "or" suggests that such states could mandate the incorporation of parenting time provisions in child support orders regardless of parental consent.

129. See Venohr, supra note 59, at 341 (noting that thirty-four state guidelines contained a shared parenting time adjustment in 2013). 
Congress recently also has focused its attention on the integration of child support determinations and parenting time. In September 2014, Congress adopted a Sense of the Congress resolution regarding parenting time arrangements. ${ }^{130}$ The Resolution states that increased parental access strengthens the parent-child relationship and leads to improved child support collection. ${ }^{131}$ It concludes that it is the Sense of the Congress that "establishing parenting time arrangements when obtaining child support orders is an important goal which should be accompanied by strong family violence safeguards," 132 and recommends that states use existing funds to establish and facilitate such programs. ${ }^{133}$ Although the resolution has no force of law, its enactment indicates growing support for the integrated "parenting time" concept. ${ }^{134}$ In addition, at least one state - Texas - has had its own such mandate in place under state law since the 1990s. ${ }^{135}$

All of these policies aim to foster an integration of child support and child custody issues that typically is available in the domestic relations context but lacking in parentage and support proceedings. However, the policies also raise fundamental questions about whether the government should play any role in allocating the childrearing rights and responsibilities of private individuals and whether, instead, this integration should be achieved through alternative means.

\section{THE UNINTENDED CONSEQUENCES OF WELL-INTENTIONED "PARENTING TIME" POLICIES}

The federal proposals to integrate parenting time provisions in state-initiated child support determinations are well-intentioned. In some respects, the proposals may be understood as a logical extension of existing family court practices. The substantive issues of child custody, visitation, and support are interrelated: whether and how parents share physical caretaking of children impacts parents' financial support responsibilities; and financial support responsibilities impact the time parents have to devote to caretaking. ${ }^{136}$ State

130. 2014 Congressional Resolution, supra note 40.

131. Id. at 303(a)(2).

132. Id. at $303(\mathrm{~b})(1)$

133. Id. at 303(b)(2) ("States should use existing funding sources to support the establishment of parenting time arrangements, including child support incentives, Access and Visitation Grants, and Healthy Marriage Promotion and Responsible Fatherhood Grants.").

134. See Christopher M. Davis, "Sense of” Resolutions, Congressional Research SERVICE (2013), available at http://fas.org/sgp/crs/misc/98-825.pdf, archived at http://perma.cc/ NPE3-DESS.

135. TeX. FAm. Code AnN. $§ 153.007$ (West 2015); see also OfFICE OF ChILD Support Enforcement, Dep't of Health \& Human Servs., Child Support and Parenting Time: IMPROVING COORDINATION TO BENEFIT CHILDREN (2013), available at http://www.acf.hhs.gov/ sites/default/files/programs/css/13_child_support_and_parenting_time_final.pdf, archived at http://perma.cc/6LHE-TNHY.

136. See, e.g., Brummer \& Flaccus, supra note 60, at 18 ("The fact that there is court concern 
laws acknowledge this interrelationship. Many state child support guidelines, for example, recognize that costs to support children differ depending on the amount of time each parent cares for the child. ${ }^{137}$ Some custody statutes consider parents' financial means when assessing what caretaking arrangement will serve the best interests of the child. ${ }^{138}$ Integrated resolution of custody and child support issues is routine in dissolution and domestic relations proceedings ${ }^{139}$ The proposed integration also comports with trends in family court policy promoting a "one judge/one family" structure, which is meant to enable a court to holistically address the needs of families. ${ }^{140}$

The parenting time proposals are also intended to encourage noncustodial parents (largely, fathers) to engage with their children, undoubtedly a laudable goal. Studies have shown that when parents cohabit or have an ongoing relationship, the likelihood that fathers will care for their children both physically and financially is much greater. When the relationship ends or when parents never have more than a casual relationship, it can be difficult for a father to develop and sustain a relationship with his child, ${ }^{141}$ particularly if the child's mother is in another relationship. ${ }^{142}$ By linking determinations of support,

for the commingling of substantive issues of child support and child custody acknowledges the fact that these issues are often . . interrelated."); Brian Jay Nicholls, Reduction in Child Support for Extended Visitation in Utah: Extra-Credit or Financial Time-Out?, 11 J. L. \& FAM. STUD. 193, 194 (2008).

137. See, e.g., D.C. CoDE $\S 16-916.01$ (2014) (adjusting the presumptive guideline amount or depart from the presumptive amount altogether when a threshold of joint caretaking or shared parenting is reached); UTAH CODE ANN. § 78B-12-216 (West 2014); see generally Venohr, supra note 59 , at 341 .

138. See, e.g., D.C. CodE $\S 16-914$ (c)(2014); LA. Civ. Code ANN. Art. 134 (West 2014); Mont. Code AnN. § 40-4-212 (West 2015); Tenn. CodE AnN. § 36-6-106 (West 2014).

139. 27C C.J.S. Divorce $\S 976$ (2014).

140. See, e.g., D.C. CODE $\$ 11-1104$ (2015) (codifying the "one family, one judge" principle); Joseph M. Lauria \& Sharon S. Townsend, A Decade of Reform in the New York State Family Courts, N.Y.ST. B.J., 46, 46-47 (2008); Erin J. May, Social Reform for Kentucky's Judicial System: The Creation of Unified Family Courts, 92 KY. L.J. 571, 591 (2004); see generally NATIONAL Council of Juvenile And FAmily Court Judges, Project ONE Key PrinciPles 1 (2012), available at http://www.ncjfcj.org/resource-library/publications/project-one-key-principles, archived at http://perma.cc/PT6N-G6GA.

141. Maldonado, supra note 114, at 993; but see Jennifer Sumi Kim, A Father's Race to Custody: An Argument for Multidimensional Masculinities for Black Men, 16 BERKELEY J. AFR.AM. L. \& POL'Y 32, 61 (2014) (noting that forty-four percent of noncustodial African-American fathers visit regularly with their children).

142. Robert I. Lerman, Capabilities and Contributions of Unwed Fathers, 20 THE FUTURE OF ChILdRen 64 (2010); see also Maria Cancian \& Daniel R. Meyer, Testing the Economic Independence Hypothesis: The Effect of an Exogenous Increase in Child Support on Subsequent Marriage and Cohabitation, 51 DEMOGRAPHY 857, 874-77 (2014) (studying noncustodial fathers' contributions when mothers have children with new partners); see also Kohn, supra note 120, at 540 . 
custody, and visitation, it is possible to encourage fathers to engage in all aspects of parenting: physical, emotional, and financial caretaking. ${ }^{143}$

The parenting time proposals also may be an attempt to correct the procedural imbalances that have been caused by federal and state child support policies. ${ }^{144}$ Such policies mandate the expedited scheduling of parentage and child support hearings, ${ }^{145}$ and offer the assistance of government personnel - including attorneys in states that establish support through court processes - to parents seeking child support without charge or for a nominal fee. ${ }^{146}$ In such cases, the government handles service of process, locates income and assets through numerous state and federal databases, prepares and files required documents and pleadings, and takes the lead in judicial and administrative proceedings for the benefit of the state and the custodial parent. ${ }^{147}$ By contrast, unless able to retain counsel, a noncustodial parent seeking visitation or a custodial parent who wishes to formalize caretaking arrangements through a domestic relations proceeding must pursue the action independently. ${ }^{148}$ Filing fees can be substantial, service of process requirements are complex, gathering and presenting evidence to the court can be challenging, and there is a dearth of legal representation options for low-income litigants. ${ }^{149}$ This exclusion of custody and visitation issues from the jurisdiction of child support courts can lead to inadequate, partial remedies for families and perceptions that the

143. See Kim, supra note 141, at 61; Maldonado, supra note 114, at 1003; Jane C. Murphy, Legal Images of Fatherhood: Welfare Reform, Child Support Enforcement, and Fatherless Children, 81 Notre DAME L. ReV. 325, 374 (2005); see generally Ann Cammett, Deadbeats, Deadbrokes, and Prisoners, 18 GeO. J. ON POVERTY L. \& POL'Y 127 (2011). Often, custodial parents want fathers to be more involved with the caretaking of children. Linking these issues could help establish the expectation that taking responsibility for one's children means more than simply financially supporting children. $I d$.

144. See Paul K. Legler, The Coming Revolution in Child Support Policy: Implications of the 1996 Welfare Act, 30 FAM. L.Q. 519, 533 (1996).

145. See, e.g., D.C.CODE $§ 16-924$ (2014) (prescribing that procedures for expedited hearings on child support, which require the judge to make "findings of fact and conclusions of law," which must occur within thirty days after the hearing ends); see also Legler, supra note 144, at 533.

146. The assistance provided by such agencies is not equivalent to individualized legal representation. Custodial parents are not considered clients by such agencies and the substantial case dockets typically managed by state child support attorneys prevent such attorneys from offering custodial parents much individual attention. See Paula Roberts \& Michael Allen, An AFDC Mother's Right to Counsel: Custody Issues in Proceedings Instigated by the IV-D Agency, 19 CLEARINGHOUSE REV. 278 (1985-1986). Nonetheless, as this section describes, the resources provided by state child support agencies enable many parents to pursue child support much more effectively than they could do on their own.

147. See Legler, supra note 144, at 538, 544, 551.

148. See supra note 28; Murphy, supra note 143, at 924-26.

149. Id.; see also Jona Goldschmidt, The Pro Se Litigant's Struggle for Access to Justice, 40 FAM. CT. REV. 36 (2002); infra notes 271-72 and accompanying text. 
adjudicatory process is unfair. ${ }^{150}$

Although integrating custody and visitation issues within child support proceedings offers several potential benefits, the federal proposals present serious challenges that merit careful consideration and a measured approach. ${ }^{151}$

\section{A. Erosion of Fundamental Parental Rights}

The integration of parenting time determinations in every state-initiated child support case, which would be mandated by the Obama Administration's budget proposal and also could result from the HHS proposed regulation, burdens parents' ability to choose whether and how much of their family lives to submit to court scrutiny and governance. ${ }^{152}$ The Due Process Clause of the Fourteenth Amendment provides that parents have a fundamental liberty interest in making decisions regarding the care, custody, and control of their children, as well as a privacy interest in freedom from unwarranted interference in the exercise of their parental duties. ${ }^{153}$ These interests are not absolute; they are balanced against the state's parens patriae role of preserving and promoting the welfare of the child. ${ }^{154}$ Yet, "so long as a parent adequately cares for his or her children (i.e., is fit), there will normally be no reason for the State to inject itself into the private realm of the family to further question the ability of that parent to make the best decisions concerning the rearing of that parent's children." 155 In other words, the law presumes that "fit parents act in the best interests of their children."156 "The Due Process Clause does not permit a State to infringe on the fundamental right of parents to make child rearing decisions simply because a state judge believes a 'better' decision could be made."157 Absent a compelling state interest, states may not infringe upon parents' rights to raise their children as they see fit. ${ }^{158}$

150. Greg Geisman, Strengthening the Weak Link in the Family Law Chain: Child Support and Visitation As Complementary Activities, 38 S.D. L. REV. 568, 578-81 (1993).

151. See Hatcher, supra note 93, at 1039.

152. See Administration's FY 2014 Budget, supra note 37; HHS 2014 Notice of Proposed Rulemaking, supra note 41; see also Nepomnyaschy \& Garfinkel, supra note 114.

153. Troxel v. Granville, 530 U.S. 57, 65-66 (2000).

154. Zurek, supra note 63, at 377-83 (discussing the development of parens patriae).

155. Troxel, 530 U.S. at 68-69.

156. Id. at 68 (citing Parham v. J. R., 442 U.S. 584, 602 (1979)).

157. Id. at $72-73$.

158. Id. at 70-73 (holding that the State cannot infringe on the parent's fundamental right to make childcare decisions and that "the court must accord at least some special weight to the parent's own determination" about the care of a child); see also Wisconsin v. Yoder, 406 U.S. 205, 228-29 (1972) (finding that imposing compulsory education against the religious wishes of parents was not a compelling interest because it was a relatively new development and that the state's interest did not outweigh the religious interests of parents); Prince v. Massachusetts, 312 U.S. 158, 167 (1944) ("[S]tate action . . . must fall unless shown to be necessary for or conducive to the child's protection against some clear and present danger."); Meyer v. Nebraska, 262 U.S. 390, 399401 (1923) (finding that the liberty interest protected by the Due Process Clause includes the right 
Although the federal proposals purport to address the narrow issue of parenting time and do not mention custody rights, in reality, orders created pursuant to each proposal would allocate rights of custody between parents. ${ }^{159}$ A court order setting forth a schedule of parenting time for one parent has two significant effects. First, by guaranteeing one parent's access to a child during particular periods of time, a parenting time order potentially limits that parent to spending only those periods of time with the child. ${ }^{160}$ Second, by carving out a limited amount of time for one parent, a "parenting time" order implicitly awards all other time to the child's other parent, thereby determining defacto primary physical custody. ${ }^{161}$ For clarity, and to avoid future litigation, such orders likely would need to designate the legal custody rights of parents as well. As a result, such agreements would have a far more significant impact than suggested by the terminology used in the proposals.

The proposals could require parents, as a condition of receiving TANF benefits or state assistance with a child support case, to establish court orders allocating their rights of custody. ${ }^{162}$ Requiring a parent to litigate his or her custodial rights would unconstitutionally infringe on a parent's right to make childrearing decisions absent a compelling state interest. As the United States Supreme Court has noted," $\mathrm{t}] \mathrm{t}$ he burden of litigating a domestic relations proceeding can itself be "so disruptive of the parent-child relationship that the constitutional right of a custodial parent to make certain basic determinations for the child's welfare becomes implicated." 163

Parents who apply for TANF already must assign their rights to collect child support to the state and, in most cases, must participate in state efforts to pursue and enforce child support orders if such parents wish to continue receiving public benefits. ${ }^{164}$ If enacted, the proposed policies presumably would similarly disqualify custodial parents who object to pursuing a parenting time order from receiving public benefits. Noncustodial parents who are defendants in stateinitiated cases would lack even this fraught choice for they would be required to

of parents to raise and control their children's education).

159. Administration's FY 2014 Budget, supra note 37; HHS 2014 Notice of Proposed Rulemaking, supra note 41. Some states, such as Ohio and Tennessee have changed the "custody" and "visitation" terminology traditionally used in domestic relations law to encourage cooperation and replaced them with "parental responsibility" and "parenting time." OHIO REV. CODE ANN. § 3109.051 (West 2014); TENN. CODE ANN. § 36-6-106 (West 2014).

160. See Donald T. KRAMER, Legal Rights OF CHILDREN, $\$ 3.2$ (2d. ed. 2014) (describing how this impacts the custodial parent: "during the time when the noncustodial parent is visiting with his or her children, the custodial parent is normally considered not to be entitled to visit with the child").

161. Id.

162. Administration's FY'14 Budget, supra note 37; HHS 2014 Notice of Proposed Rulemaking, supra note 41.

163. Troxel v. Granville, 530 U.S. 57, 75 (2000) (internal citations omitted).

164. 42 U.S.C. $\S 608(a)(3)$ (2014); 42 CFR $\S 433.146(a)$ (2014); 42 CFR $\S 433.148(a)(1)$ (2014). 
address parenting time in all cases in which a custodial parent received state child support services. ${ }^{165}$

No compelling state interest exists to justify a blanket policy limiting parents' discretion to choose whether to adjudicate custody in state-initiated child support determinations. ${ }^{166}$ Some might justify such proposals as imposing an appropriate, additional quid pro quo for the receipt of welfare benefits; however, the relationship of state public benefits expenditures to the entry of custody orders is much more attenuated. Unlike the child support orders entered under this program, custody and visitation orders would not directly result in increased child support collection, and therefore would not further the government's ostensible pecuniary interest in cost recapture. ${ }^{167}$ Although there is some evidence that enhanced interactions between noncustodial parents and children may lead to increased child support collection, the evidence is not sufficiently conclusive to justify the blanket imposition of custody orders as a means to advance the state's interest in preventing future welfare dependency. ${ }^{168}$ Similarly, the proposals' aims of making court processes more accessible do not justify mandatory government involvement in the constitutionally protected sphere of parental decision-making. ${ }^{169}$

\section{B. Negative Consequences of Court Involvement in Childrearing Decisions}

The Obama Administration and HHS proposals would bring custody arrangements under court review between parents who may neither need nor want court involvement. Custody orders can be harmful to families that are managing fine without them. ${ }^{170}$ Funneling families to court in the absence of conflict risks depleting family resources, generating conflict, and upending settled parenting arrangements. ${ }^{171}$ Child custody cases involve high stakes and often become contentious and adversarial. ${ }^{172}$ The adversarial nature of child custody proceedings and the types of information courts must consider in awarding custody and visitation pit parents against one another and may encourage parents to view the proceeding as a zero-sum game. ${ }^{173}$ Child custody

165. Hatcher, supra note 93, at 1066; see also Administration's FY 2014 Budget, supra note 37.

166. Troxel, 530 U.S. at 96.

167. See supra note 31.

168. See generally Huang, supra note 116.

169. See supra note 1.

170. See generally Joan B. Kelly, Psychological and Legal Interventions for Parents and Children in Custody and Access Disputes: Current Research and Practice, 10 VA. J. Soc. PoL'Y \& L. 129, 131-32 (2002); Weinstein, supra note 1, at 123-34.

171. Kelly, supra note 170, at 131; see generally Weinstein, supra note 1, at 123-34.

172. See, e.g., Jana B. Singer, Dispute Resolution and the Postdivorce Family: Implications of a Paradigm Shift, 47 FAM. CT. REV. 363, 363 (2009).

173. See Kelly, supra note 170 , at 130-31. 
proceedings also can be invasive. ${ }^{174}$ Courts may direct social services officers to conduct studies of parents' residences or require parents to undergo psychological evaluation. ${ }^{175}$ Children can be impacted negatively by the increased conflict and stress the litigation generates for their parents. ${ }^{176}$ For all of these reasons, custody litigation is taxing on parents, and the entry of a court custody order may place parents in a worse position to commence a shared parenting arrangement than they would be without a court order. ${ }^{177}$

Perhaps especially in TANF cases, parents may not need or want court intervention to manage their co-parenting relationships. ${ }^{178}$ Parents only need to seek court intervention to distribute custody and visitation rights when they are unable to devise a workable division of parenting responsibilities on their own. ${ }^{179}$ Because it is state driven, the initiation of a TANF-related child support case does not necessarily signal the existence of conflict between the parents around matters relating to the child. ${ }^{180}$ Further, several studies suggest that many fathers whose children receive TANF have relationships and spend time with their children. ${ }^{181}$ Imposing a formal court ordered schedule of custody and visitation may undermine the arrangements that parents have created to exercise their custodial rights. ${ }^{182}$

In cases where a custodial parent affirmatively seeks state agency services outside of the TANF context, it is more likely that either no relationship or a conflict-ridden relationship exists between the parents. ${ }^{183}$ A custodial parent may seek to establish parentage when the father's identity is unknown, or prior voluntary arrangements for financial support have broken down. ${ }^{184}$ A noncustodial parent may have failed to visit and interact with the child on a

174. See e.g., Murphy, supra note 72, at 911-14.

175. See id.

176. See, e.g., Kelly, supra note 170, at 131-32.

177. $I d$.

178. Hatcher, supra note 93, at 1045.

179. For example, parents might need a court order if they cannot agree on a child's residence or visitation schedule, cannot rely on one another to adhere to scheduling agreements, or do not want to share decision-making authority. See, e.g., ELROD, supra note 3, at $\S \S 4.1,4.34$. Many clients of Columbus Community Legal Services choose not to seek adjudication of child custody in the context of divorce and domestic violence civil protection order proceedings for many reasons, including that: they are happy with how things are working, they worry that court proceedings will create conflict or change arrangements that have been successful, or they fear that pursuing custody could provoke an abusive co-parent.

180. Turetsky, supra note 26, at 411 n.53. Similarly, continued involvement of the IV-D agency in a former-TANF case, does not necessarily signal the existence of conflict between the parents around matters relating to the child. Many former TANF recipients do not realize that they can discontinue IV-D services once they are no longer receiving benefits.

181. See Huntington, supra note 51, at 185-96.

182. See Nepomnyaschy \& Garfinkel, supra note 114 , at 370 .

183. See id. at 342 .

184. See id. 
regular basis and eventually ceased to pay support. ${ }^{185}$ In some cases, custodial parents may have been reluctant to work out an informal support arrangement due to fear of domestic violence but may be seeking state child support services despite such fears because of increasing financial need. ${ }^{186}$

In more conflict prone cases, noncustodial parents often report that custodial parents have affirmatively impeded or prevented them from seeing their children or used payment of financial support to control the noncustodial parent's access to his children. ${ }^{187}$ Some report that the custodial parent is involved in a new relationship and does not want the noncustodial parent involved in her life. ${ }^{188}$

Although there may be an increased likelihood of parental conflict and a greater need for third party assistance to facilitate formal support and caretaking arrangements in these non-TANF cases, ${ }^{189}$ a blanket mandate that parents must submit their custody arrangements to court review, in the context of a stateinitiated case, could be problematic for both custodial and noncustodial parents. ${ }^{190}$

Non-TANF custodial parents receiving state child support agency services are typically low wage earners in difficult financial straits. ${ }^{191}$ As a condition of receiving state services, the mandate would place these custodial parents in the untenable position of having to address custody and visitation issues with a parent who, in some cases, has not been involved with the children or has never expressed interest in visitation. Yet that parent will now have an opportunity to obtain a parenting time order in a context where the more time a visitation order authorizes, the lower the child support that the noncustodial parent has to pay. ${ }^{192}$ Moreover, the action would be initiated by the state child support authorities who represent the interests of the state, not the custodial parent. Custodial parents report that the current state child support process often relegates them to the sidelines where they are ignored, dispensable, and disempowered. ${ }^{193}$ The proposals are also potentially harmful to noncustodial parents. Although some noncustodial parents desire more time with their children and may have been denied access to them inappropriately, addressing custody and visitation issues in a streamlined, mandatory process in high volume child support courts may encourage noncustodial parents to enter into standardized agreements that could limit their rights to caretaking and decision-making in exchange for parenting

185. See Huang, supra note 116, at 58-60; see also Nepomnyaschy \& Garfinkel, supra note 114 , at 343 .

186. See Hatcher, supra note 93 , at 1045.

187. See Huang, supra note 116 , at 54 .

188. See Nepomnyaschy \& Garfinkel, supra note 114 , at 343.

189. See Hatcher, supra note 93, at 1036.

190. See id. at 1049-50.

191. See id.

192. Id. at 279 .

193. Hatcher, supra note 93, at 1066; see also Lisa Kelly, If Anybody Asks You Who I Am: An Outsider's Story of the Duty to Establish Paternity, 6 YALE J.L. \& FEMINISM 297 (1994). 
time. ${ }^{194}$ Noncustodial parents who desire shared custody or a formalized visitation arrangement also should not have to rely on, and are unlikely to trust, the state agency whose primary mission is to collect child support from them. ${ }^{195}$ Noncustodial parents often perceive the state-initiated child support process as adversarial, embarrassing, and frustrating. ${ }^{196}$ The traditional cost capture mission of state child support agencies has led to the perception among noncustodial parents that the agency's purpose is largely punitive in nature. ${ }^{197}$ Despite efforts to change this brand and move from a focus on "deadbeat dads" to "deadbroke dads," the agency remains an arm of the government and may continue to be perceived as unfriendly or indifferent to the needs of low-income families. ${ }^{198}$ This reflects a generally negative perception of the government among the poor, whose interactions with the government frequently include negative encounters with the police, social service agencies, and intractable government bureaucracies. ${ }^{199}$ Custodial and noncustodial parents who desire court adjudication of their rights to custody and visitation should have a meaningful and accessible process available to them.

The involvement of noncustodial parents, particularly fathers, in the lives of their children is a concern with regard to families in all income groups. ${ }^{200}$ Yet, given the population of parents served by state child support programs, the parenting time proposals disproportionately would impact low-income families. ${ }^{201}$ The proposals would impose burdens on low-income unmarried

194. See infra Part II.A (discussing the misleading nature of the term "parenting arrangements" and implications for custody).

195. Hatcher, supra note 93, at 1077.

196. Id.; Murphy, supra note 143, at 374; see also Cammett, supra note 143, at 133.

197. Id.

198. See supra Part I.B; Dep't of Health and Human Servs., Office of Child Support Enforcement, NATIONAL ChiLd SupPort Strategic Plan FY 2010-2014 (2013), available at http://www.acf.hhs.gov/programs/css/resource/national-child-support-strategic-plan-fy-2010-2014, archived at http://perma.cc/YS82-RQCW.

199. Many low-income individuals have high levels of mistrust of government due to their interactions with law enforcement and social services. Low-income men in particular (especially African American and Latino men) have often had very negative interactions with the police and the justice system. See generally Keith D. Parker et al., African-Americans' Attitudes Toward the Local Police: A Multivariate Analysis, 25 J. BLACK STUD. 396 (1995).

200. Gretchen Livingston \& Kim Parker, Pew Research Ctr., A TAle of Two Fathers: More Are ACtive, But More ARE ABSENT 12 (2011), available at: http://www.pewsocialtrends. org/files/2011/06/fathers-FINAL-report.pdf, archived at http://perma.cc/4RQU-445J (“Some 15\% of fathers with annual family incomes of $\$ 50,000$ or more live apart from a child, compared with $39 \%$ of those with incomes below $\$ 30,000$ and $38 \%$ of those with incomes of $\$ 30,000$ to \$49,999”); see also Kohn, supra note 120, at 516-19.

201. In 2009, seventy-nine percent of all "custodial families" in the United States with incomes below the federal poverty threshold received services from state child support agencies, (custodial families are defined as families in which a child lives with one parent and the child's other parent lives outside of the household); sixty-three percent of custodial families receiving state child 
parents that the state does not impose on middle and upper income families in exchange for state benefits and services. ${ }^{202}$ The federal government does not, for example, mandate that middle or upper income unmarried parents establish visitation and custody orders to qualify for the federal child tax credit ${ }^{203}$ or federal tax deductions for dependent children. ${ }^{204}$ Moreover, to the extent that the proposals would deter parents who need financial assistance from pursuing applications for public benefits or seeking state assistance with child support, the mandate could harm children. ${ }^{205}$

\section{Procedurally Inadequate Custody and Visitation Determinations}

As currently structured, the process used in judicial and administrative child support tribunals are inadequate to address the complex issues involved in determining custody and parenting time for low-income families. State-initiated child support proceedings are structured to facilitate collection. The ready availability of DNA testing made possible by federal funds has significantly reduced the occurrence of protracted parentage litigation. ${ }^{206}$ Moreover, pursuant to the Family Support Act of 1988, all fifty states and the District of Columbia

support services earned incomes below $200 \%$ of the federal poverty threshold. KYE LIPPOLD \& Elaine Sorensen, Urban Institute, Characteristics of Families Served by the Child Support (IV-D) Program: 2010 Census Survey Results, 5, 14 (2013), available at http://www.urban.org/research/publication/characteristics-families-served-child-support-iv-dprogram-2010-census-survey, archived at http://perma.cc/CE62-AWZL. The report concludes that the "[c]ustodial families most likely to receive [state child support] services are poor, nevermarried, younger, and less educated" than custodial families not receiving state child support services. Id. at 14 .

202. See 26 U.S.C. $\S \S 24,151,152$ (2014).

203. Unmarried parents earning gross incomes of up to $\$ 75,000$ (each) can qualify for the federal child tax credit. Id.

204. Some might resist such a comparison as ill-fitting: in the public benefits context, such parents already are required to initiate proceedings to collect child support, and a custody order simply would add an additional dimension to the order that results. Yet, the goal of recapture of public benefits costs is itself a public policy choice that is not pursued in the tax context, perhaps for reasons related to the types of parents impacted by the respective policies. See, e.g., Jim Carlin et al., Civil Justice and the Poor: Issues for Sociological Research, 1 LAW \& Soc'Y REV. 9, 12 (1966) ("[T] he law is not a neutral instrument, but rather that it is oriented in favor of those groups or classes in society having the power to bend the legal order to their advantage").

205. See Ariel Kalil \& Rebecca M. Ryan, Mothers' Economic Conditions and Sources of Support in Fragile Families, 20 FragiLE FAMILIES 39, 47-57 (2010) (identifying cash benefits and private support as important sources of support for unwed mothers in fragile families). But see Robert I. Lerman, Capabilities and Contributions of Unwed Fathers, 20 FrAGILE FAMILIES 63, 77 (2010) (discussing the possible detrimental impact of formal child support collection on informal support payments).

206. Christopher L. Blakesley, Scientific Testing and Proof of Paternity: Some Controversy and Key Issues for Family Law Counsel, 57 LA. L. REV. 379, 379-80 (1997). 
adopted detailed child support guidelines, which presumptively dictate the amount of child support owed and allow courts to compute child support obligations with minimal individualized fact-finding in most cases ${ }^{207}$ In the many states that consider custodial parents to be witnesses - not parties - to stateinitiated child support cases, custodial parents are neither entitled to receive formal notice of nor participate in hearings unless they intervene in or join the case. ${ }^{208}$ Discovery, contested trials, and detailed motions hearings are relatively rare in child support courtrooms. ${ }^{209}$ Federal mandates also have dictated that parentage and child support hearings be scheduled on an expedited basis, with initial hearings scheduled within forty-five days of filing the action. ${ }^{210}$ State statutes further give trial and administrative courts broad long arm jurisdiction over noncustodial parents. ${ }^{211}$

Child custody proceedings, by contrast, typically are structured to accommodate individualized fact-finding and are governed by separate jurisdictional requirements. Adjudicators in custody and visitation cases generally do not rely on scientific tests or mathematical formulas to simplify judicial decision-making. ${ }^{212}$ Although a few states have adopted visitation or parenting time guidelines that offer presumptive or minimum amounts of visitation to a noncustodial parent when parents cannot agree on a caretaking arrangement, ${ }^{213}$ the majority of states require courts to engage in individual factfinding and adjudication to resolve contested custody and visitation cases. ${ }^{214} \mathrm{In}$ such cases, courts typically issue written findings on a number of factors to support a determination that a particular custody arrangement serves the best interest of a child. ${ }^{215}$ Courts and parties may enlist social workers, mental health professionals, and guardians ad litem to present a fuller picture of a family, and parties are entitled to present a broad range of evidence related to the caretaking of children. ${ }^{216}$ Developing and sifting through this evidence takes time.

That domestic relations and dissolution courts are structured to accommodate more detailed fact-finding is not to suggest that low-income parents have the same access to these processes as higher income parents who retain private counsel. Scholars have highlighted the pressures family courts exert on pro se parties to resolve their disputes through mediation and the barriers that prevent

207. 42 U.S.C. $§ 667$ (a) (2014); Murphy, supra note 143, at 346-47.

208. Brustin, supra note 98 , at 44,73 ; see supra Part I.B.

209. See infra note 231.

210. Legler, supra note 144, at 533.

211. Unif. Interstate Family Support Act (amended 2001), 9 U.L.A. 255 (Supp. 2001).

212. Linda D. Elrod \& Milfred D. Dale, Paradigm Shifts and Pendulum Swings in Child Custody: The Interests of Children in the Balance, 42 FAM. L.Q. 381, 385 (2008).

213. See, e.g., InD. PARENTING TIME GuIdELINES $\S$ IIA1-3 (2011); S.D. CodifiEd LAWs $\S \S$ 25-4A-10, 25-4A-11 (2014); UTAH CODE ANN. §§ 30-3-35; 30-3-35.5 (2014).

214. ELROD \& DALE, supra note 59, at 392-93.

215. Lynne Marie Kohm, Tracing the Foundations of the Best Interests of the Child Standard in American Jurisprudence, 10 J. L. \& FAM. STUD. 337, 352 (2008).

216. ELROD, supra note 3, at $\S 11: 2$. 
parents from effectively representing themselves in domestic relations proceedings. ${ }^{217}$ Nonetheless, as compared to the general capacity of domestic relations and dissolution courts to handle child custody disputes, child support courts arguably have even fewer resources of time, expertise, and physical space to enable them to accommodate custody and visitation proceedings. ${ }^{218}$

In further contrast to child support proceedings, in domestic relations and dissolution matters both legally recognized parents are considered parties to the case. $^{219}$ Both parents are entitled to notice of the proceedings, usually by personal service or some other more reliable means of notification, and an opportunity to be heard on the issues of custody and visitation. ${ }^{220}$

Finally, court jurisdiction over custody matters is governed by a specialized regime of federal and uniform state laws, which generally permit courts to adjudicate custody and visitation issues only if the jurisdiction is the "home state" of the child. ${ }^{221}$ A child's "home state" is that in which the child and at least one parent have resided for the six months preceding the filing of the action. ${ }^{22}$ A state that has long-arm jurisdiction to initiate a child support proceeding may not also qualify as a child's home state for purposes of child custody jurisdiction.

For all of these reasons, incorporating custody and access into state initiated child support proceedings raises procedural due process concerns. The Fourteenth Amendment mandates that a fair process must precede any deprivation of the liberty interests protected by the due process clause, including the right to the care and custody of children. ${ }^{223}$ Due process guarantees parents notice and a hearing before custody rights may be deprived. ${ }^{224}$ Yet, in many

217. Russell Engler, And Justice for All-Including the Unrepresented Poor: Revisiting the Role of Judges, Mediators and Clerks, 67 FORDHAM L. REV. 1987, 206-07 (1999); Murphy, supra note 72 , at $922-23$.

218. Rebecca Love Kourlis et al., Iaals' Honoring Families Initiative: Courts and Communities Helping Families in Transition Arising from Separation or Divorce, 51 FAM. CT. REV. 351, 356 (2013).

219. Brustin, supra note 98 , at 44.

220. U.S. Const. amend. XIV, § 1; see, e.g., Holm v. Smilowitz, 840 P.2d 157, 164 (Utah Ct. App. 1992); see also infra notes 223-24.

221. See, e.g., D.C. CodE ANN. § 16-4602.01 (2014); NEV. REv. StAT. § 125A.085 (2014); S.C. CODE ANN. § 63-15-330 (2014); TEX. FAM. CODE ANN. § 152.201 (2014).

222. See, e.g., D.C. Code ANN § 16-4601.01 (2014); NeV. Rev. StAT. ANN. § 125A.005 (2014); S.C. Code ANN. § 63-15-300 (2014); TEX. FAM. CODE ANN. § 152.001 (2014).

223. U.S. Const. amend. XIV, § 5; see, e.g., Mabe v. San Bernardino Cnty., Dep't of Pub. Soc. Servs., 237 F.3d 1101 (9th Cir. 2001); Fawcett v. Gooch, 708 N.E.2d 908 (Ind. Ct. App. 1999); Keisling v. Keisling, 92 S.W.3d 374, 377 (Tenn. 2002); Holm, 840 P.2d at 164.

224. See, e.g., Evans v. Evans, 2007 Ala. Civ. App. LEXIS 496 (Ala. Civ. App. 2007) (custody order violated parent's rights to due process when parent was not provided notice of hearing at which order was entered); Van Schaik v. Van Schaik, 90 Md. App. 725 (Md. App. 1992) (court's failure to provide parents' with adequate notice that custody would be addressed violated their rights to due process). 
jurisdictions, providing both parents with notice and opportunity for hearing in state-initiated support matters would require a significant shift in current practice. ${ }^{225}$ In order to meet procedural due process muster, these states would need to ensure that custodial parents in TANF and non-TANF cases are considered parties and provide adequate notice and an opportunity for hearing regarding any visitation and custody claims.

Even when parents are provided notice, the administrative processes utilized to establish child support orders in some states may raise procedural due process concerns if extended to determinations of custody and parenting time. ${ }^{226}$ In Oregon and Maine, for example, child support orders are established by caseworkers who review parents' financial information and mail written determinations of the support amount to the parents, which are binding unless one parent requests a hearing. ${ }^{227}$ Colorado employs a similar process, with the additional requirement that the parents participate in a negotiation conference. ${ }^{228}$ Such administrative proceedings neither accord parents the opportunity to be heard, nor to respond to the claims raised against them through an evidentiary hearing.

Courts generally agree that due process requires a full evidentiary hearing before the entry of a permanent custody order in contested cases. ${ }^{29}$ Administrative proceedings that are more informal in nature, lack impartial judicial oversight, and eliminate or limit opportunities for parents to present evidence or cross-examine witnesses may run afoul of procedural due process guarantees. ${ }^{230}$

Apart from the due process implications, incorporating the adjudication of custody and visitation into the current state child support adjudication model is unsound policy. Requiring high volume child support courts to adjudicate and enter custody and visitation orders in all or most state initiated cases risks streamlining custody adjudications in a way that threatens the quality of the

225. See Brustin supra note 98 , at 43-44.

226. Under Matthews v. Eldridge, the type of hearing due process requires depends upon a weighing of "the private interests at stake, the risk of error and value of additional procedures, and the interests of the government." 424 U.S. 319, 343-44 (1976). The formality of the hearing "can vary, depending on the importance of the interests involved and the nature of the subsequent proceedings." Boddie v. Connecticut, 401 U.S. 371, 378 (1971).

227. KAREN N. GARDinER ET AL., U.S. DEP'T OF HeAlth \& HuMAN SERVICES OFFICE OF CHILD SupPort ENFORCEMENT, AdMINISTRATIVE AND Judicial Processes FOR ESTABLishing ChILD SUPPORT ORDERS, FINAL REPORT 9 (2002), available at http://mefassociates.com/pdfs/ IncomeSecPage/ChildSOrders.pdf, archived at http://perma.cc/35YV-4RVB\#_blank.

228. Id.

229. U.S. CONST. amend. XIV; Hurlman v. Rice, 927 F.2d 74 (2d Cir. 1991); Walker v. Walker, 960 P.2d 620 (Alaska 1998); Smith v. Crider, 932 So. 2d 393, 399 (Fla. Dist. Ct. App. 2d Dist. 2006).

230. See GARDINER ET AL., supra note 227, at 9; Walker v. Eldridge, 243 S.W.2d 638 (Ark. 1951); Cappetta v. Cappetta, 1490 A.2d 996 (Conn. 1985). 
determinations. ${ }^{231}$ Under current models, courts are likely to resort to issuing standardized allocations of parental rights and responsibilities rather than crafting orders that seek to serve the best interests of each child before the court. ${ }^{232}$ Once a custody and visitation order is established it can be difficult and cumbersome to change. ${ }^{233}$ If a hastily agreed upon custody arrangement does not work out or one parent fails to comply with the terms, a parent must initiate a formal, often costly, proceeding and demonstrate that there has been a substantial and material change in circumstance to justify a modification. ${ }^{234}$ None of the state IV-D agencies currently offering parenting time services provide assistance with modification or enforcement of parenting time orders. ${ }^{235}$

Child support orders integrating visitation provisions are particularly subject to manipulation because increases in "parenting time" can lead to decreases in

231. Murphy, supra note 143, at 378 (noting that the high volume of child support cases has caused states to streamline child support determinations); ROBERT LAFOUNTAIN ET AL.,NATIONAL Center for State Courts, Examining the Work of State Courts: An Analysis of 2010 STATE COURT CASELOADS 13 (2012), available at http://www.courtstatistics.org/ /media/ Microsites/Files/CSP/DATA\%20PDF/CSP_DEC.ashx, archived at http://perma.cc/WEG937KH\#_blank ("Domestic Relations matters, more so than any other category of cases, are the most likely to re-enter the court after an initial disposition as reopened cases, possibly several times, to revisit custody or support issues.").

232. See, e.g., TEX. FAM. Code ANN. $\S \S 153.251,153.252,153.3101$ (West 2013); Cf. Hatcher, supra note 25, at 910 (given the typical conditions in child support court rooms, "essentialism reigns," rather than individualized inquiry); Rebecca May, Notes from Child Support Courts: Process and Issues, in REBECCA MAY \& MARGUERITE ROULET, CTR. FOR FAMILY POLICY

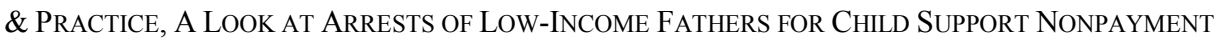
42 (2005), available at http://www.cffpp.org/publications/LookAtArrests.pdf, archived at http://perma.cc/8KBQ-LBEH (finding that an impact of high caseloads in child support courtrooms is a tendency to view noncustodial parents as "all the same").

233. In many states, a parent seeking to modify the terms of a custody order must demonstrate that a substantial and/or material change in circumstances has occurred. See, e.g., D.C. CODE $\S 16-$ 914(f)(1) (2014); TENN. CODE ANN. § 36-6-101(a)(2)(B) (West 2014); see generally ELROD, supra note 3 , at $\S 17.4$. If no circumstance has changed since the entry of an order, other than that the order has turned out not to be a good fit, a parent might not prevail in seeking modification. Parents who fail to comply with unworkable orders may be subject to contempt. Id. § 15.2. States could mitigate this risk by giving parents who enter custody and parenting time orders in child support cases greater latitude to modify such orders later; but, such a measure could further deplete family court resources by increasing the number of modification cases requiring adjudication. See, e.g., LAFOUNTAIN ET AL., supra note 231.

234. See, e.g., Robert E. Oliphant, Redefining A Statute Out of Existence: Minnesota's View of When A Custody Modification Hearing Can Be Held, 26 WM. Mitchell L. ReV. 711, 716 (2000).

235. See, e.g., Handbook for Non-Custodial Parents, AtTORney General of TeXAs, http://www.texasattorneygeneral.gov/AG_Publications/txts/qa_ncp.shtml (last visited Aug. 2, 2014), archived at http://perma.cc/Q4ZM-V3G7\#_blank; PARENTING TIMEORDERS, supra note 83, at 1 . 
the amount of child support paid under state child support guidelines. ${ }^{236}$ In most states, visitation orders specify the parameters by which parents may spend time with their children; they do not impose an enforceable obligation for parents to do so. ${ }^{237}$ Therefore it is critical for adjudicators to establish the sincerity of parental requests for shared custody and visitation and determine whether parents requesting significant visitation are capable of fulfilling such arrangements. ${ }^{238}$ Courts can modify child support orders based on inaccurate projections about the amount of time each parent ultimately spends with a child, but only if the parent seeking a change has the ability to invest the time, energy, and money involved in filing and pursuing a motion to modify. ${ }^{239}$ Establishing parenting time awards in cases where courts do not have adequate time and capacity to assess the feasibility of the arrangement may result in reduced child support awards without a concomitant increase in contact between noncustodial parents and children. ${ }^{240}$

Finally, the federal proposals are especially troubling from a procedural perspective because none contemplates providing parents with access to legal counsel. ${ }^{241}$ Government attorneys handling judicial or administrative parentage and support proceedings on behalf of the state do not represent individual parents. ${ }^{242}$ Instead, they typically represent the interests of the state in collecting support. ${ }^{243}$ Parents seeking help from a state child support agency therefore do not have a lawyer/client relationship with the agency or its attorneys, do not enjoy the ethical protections of confidentiality in their communications with state

236. See Venohr, supra note 59, at 341.

237. See, e.g., Hamilton v. Hamilton, 667 N.E.2d 1256 (Ohio Ct. App. 1995) (“"Because it is a right, not a duty, a court cannot force a nonresidential parent to visit his or her child"); James Dwyer, A Taxonomy of Children's Existing Rights in State Decisionmaking About Their Relationships, 11 WM. \& MARY BILL RTS. J. 845, 937 (2003); Kohn, supra note 120, at 512 (collecting cases declining to hold noncustodial parents in contempt for failing to exercise visitation rights).

238. See, e.g., Carter v. Dayhuff, 829 N.E.2d 560, 571 (Ind. Ct. App. 2005) (denying a request to credit parenting time in order to modify child support when parent did not exercise parenting time and had not kept child overnight in several years); Roberts \& Allen, supra note 146, at 279.

239. Although child custody is frequently identified as one of the most pressing areas of legal need for the low-income community, most low-income parents who would qualify for free legal services are unrepresented in child custody proceedings today because legal services providers lack the capacity to meet the current demand for representation. See LEGAL SERVS. CORP., supra note 28 , at 11,26 . This demand could increase significantly if all parents receiving TANF or seeking child support through IV-D agencies must formalize custody rights.

240. Supra note 236.

241. See Administration's FY'14 Budget, supra note 37; HHS 2014 NPRM, supra note 41; 2014 Congressional Resolution, supra note 40.

242. Hatcher, supra note 93, at 1079.

243. Office of Child Support Enforcement, Dep't of Health \& Human Servs., ESSENTIALS FOR ATTORNEYS IN CHILD ENFORCEMENT 34 (2002), available at_http://www.acf. hhs.gov/sites/default/files/programs/css/essentials_for_attorneys_ch04.pdf, archived at http://perma.cc/XG22-SD5V\#_blank. 
agencies, and may actually have interests that conflict with those of the state. ${ }^{244}$ Involving state agencies or their attorneys in the fashioning of "parenting time" orders would not provide parents with the legal assistance they need to protect their fundamental parental rights; in fact, under the proposals, custodial or noncustodial parents could be pitted against government attorneys who take contrary positions regarding proposed custody or visitation arrangements. ${ }^{245}$

\section{Risks to Parents Subjected to Domestic Violence}

The parenting time proposals also have the potential to put the safety and well-being of custodial parents and children at risk where there has been a history of domestic violence between parents. Parents who receive TANF report experiencing domestic violence at extraordinarily high rates. ${ }^{246}$ Between fifty and nearly seventy-five percent of TANF recipients (eighty-five percent of whom are women $)^{247}$ report having experienced abuse. ${ }^{248}$ Rates of domestic violence

244. Id. at 49; Hatcher, supra note 93, at 1080; Roberts \& Allen, supra note 146, at 278.

245. Roberts \& Allen, supra note 146, at 278; supra note 100 and accompanying text.

246. National Law CENTER On Homelessness AND Poverty, SHortchanging SuRVIVORS: The FAMily Violence Option FOR TANF Benefits (2009), available at http://www.ncdsv.org/images/NLCHP_ShortchangingSurvivorsTheFVOptionForTANFbeneftis _12-2009.pdf, archived at http://perma.cc/JF25-UWLB\#_blank; U.S. GOV'T ACCOUNTABILITY OFFICE, TANF: STATE APPROACHES TO SCREENING FOR DOMESTIC VIOLENCE COULD BENEFIT FROM HHS GUIDANCE 7 (2005), available at http://www.gao.gov/new.items/d05701.pdf, archived at http://perma.cc/C758-J6R4\#_blank. The rate at which TANF recipients report experiencing domestic violence appears significantly higher than the general rate at which domestic violence is reported in the United States. On average, approximately one in four women and one in seven men report having been the victim of severe intimate partner violence during their lifetimes; and one in three women and one in four men report having been the victim of rape, physical violence, or stalking by an intimate partner in their lifetimes. Breiding MJ et al. Prevalence and Characteristics of Sexual Violence, Stalking and Intimate Partner Violence Victimization, NATIONAL InTIMATE Partner and Sexual Violence Survey, United States, Centers for Disease Control and PREVENTION, 2011, 63 MMWR 1-18 (2014).

247. Office of Family Assistance, U.S. Dep't of Health and Human Servs., CHARACTERISTICS AND FINANCIAL CIRCUMSTANCES OF TANF RECIPIENTS: FisCAL YEAR 2010 (2012), available at http://www.acf.hhs.gov/programs/ofa/resource/character/fy2010/fy2010chap10-ys-final, archived at http://perma.cc/9P68-M4CP\#_blank.

248. MAtThew Breiding ET AL., NATIONAL CENTER FOR INJURy PREVENTION AND CONTROL, Centers for Disease Control and PreVention, Intimate Partner Violence in the United STATES-2010 2 (2014), available at http://www.cdc.gov/violenceprevention/pdf/cdc_nisvs_ ipv_report_2013_v17_single_a.pdf, archived at http://perma.cc/VFP5-4787\#_blank; see also Eleanor Lyon, NATional Resource Center on Domestic Violence, Welfare, Poverty AND ABUSED WOMEN: NEW RESEARCH AND ITS IMPLICATIONS 1 (2000), available at http:// www.vawnet.org/advanced-search/print-document.php?doc_id=771\&find_type=web_desc_ NRCDV, archived at http://perma.cc/4RXX-PHUT\#_blank (stating that fifty percent of welfare recipients report experiences with Domestic Violence compared to twenty-two percent of women 
also are likely to be high among non-TANF custodial parents working with state child support agencies. ${ }^{249}$ Among custodial parents working with state child support agencies, approximately forty-three percent formerly received TANF, ${ }^{250}$ and approximately eighty seven percent are single mothers residing with their children. ${ }^{251}$ In 2010 single women living with children were ten times more likely to experience intimate partner violence than married women living with children and six times more likely than single women living alone. ${ }^{252}$

The streamlined procedures used in child support adjudications are particularly inadequate to address custody and visitation in cases involving a history of domestic violence. First, the expedited proceedings might limit parents' opportunities to disclose abuse to the court, as a matter may be finally resolved after one abbreviated hearing, rather than the two or three appearances typical of many domestic relations cases.

Second, cases involving a history of domestic violence are complex. There is often a high level of conflict between the parents and these cases may be more likely to result in contested hearings. ${ }^{253}$ Allegations of domestic violence often require detailed fact-finding by judicial officers, as parents may lack corroborating evidence, and such allegations often are hotly contested--not only because they may be personally embarrassing but also because they have significant legal implications. In many states, findings of domestic violence trigger legal presumptions about how custody should be awarded. ${ }^{254}$ Nearly all states mandate that courts consider a finding of domestic violence when awarding custody, and several states require that courts justify awards of custody or visitation to a parent who has perpetrated abuse with written findings that

in the general population); PATricia TJAden \& NANCy Thoennes, OfFiCE OF Justice Programs, NAtional Institute of Justice, U.S. DePt. OF Justice, EXTENT, NATURE, AND CONSEQUENCES OF INTIMATE PARTNER VIOLENCE iii (2000), available at https://www.ncjrs.gov/pdffiles1/nij/ 181867.pdf, archived at http://perma.cc/8TSQ-99WV\#_blank (finding that twenty-five percent of women experience domestic violence in their lifetimes).

249. See generally Richard M. Tolman \& Jody Raphael, A Review of Research on Welfare and Domestic Violence, 56 J. SOC. ISSUES 655 (2000).

250. SOLOMON-FEARS, supra note 18, at 4-5.

251. See LiPPOLD \& Sorensen, supra note 201, at 5.

252. ShanNAN CATALANO, INTIMATE PARTNER VIOLENCE, 1993-2010 7 (2012), available at http://www.bjs.gov/content/pub/pdf/ipv9310.pdf. archived at http://perma.cc/98BH-E2BQ.

253. Robert B. Straus, Supervised Visitation and Family Violence, 29 FAM. L. Q. 229, 230-49 (1995).

254. American Bar Association COMmission on Domestic Violence, Joint Custody PRESUMPTIONS AND DOMESTIC VIOLENCE EXCEPTIONS (2014), available at http://www. americanbar.org/content/dam/aba/administrative/domestic_violence1/Charts/2014\%20Joint\%20 Custody\%20Chart.authcheckdam.pdf, archived at http://perma.cc/Q6HX-T2N3; AMERICAN BAR Association Commission on Domestic Violence, Child Custody and Domestic Violence BY STATE (2014), available at_http://www.americanbar.org/content/dam/aba/administrative/ domestic_violence1/Charts/2014\%20Custody\%20DV\%20Chart.authcheckdam.pdf, archived at http://perma.cc/L2QH-KEJ2. 
account for the safety of the child and the abused parent. ${ }^{255}$ Courts often involve guardians ad litem or other social services professionals in custody cases involving allegations of domestic violence to give them greater insight into the circumstances of the parties and the child.

Third, many custody cases involving a history of domestic violence give rise to safety concerns for parents and children, which courts may need to address and monitor regardless of whether parenting time orders result from adjudication or voluntary agreement. ${ }^{256}$ Parents may be required to disclose their residential addresses to courts in conjunction with custody proceedings, which may directly or inadvertently inform an abusive co-parent of a victimized parent's location. The frequent interactions between parents required by visitation exchanges and related communications may result in renewed violence and emotional abuse. States have recognized the complexity domestic violence adds to custody determinations and implemented statutes that require courts to issue custody orders that directly address domestic violence concerns. To establish effective safeguards, a court may need to consider the location, supervision, and timing of visits and exchanges of children, and revisit and adjust conditions that prove ineffective. ${ }^{257}$

Determinations of custody and parenting time when allegations of domestic violence are involved require careful, individualized attention and can strain the resources even of the courts that traditionally have been set up to adjudicate them. Court resources may be further strained by such cases because mediation, which is often used or required in domestic relations courts, may not be viable or safe in cases involving a history of domestic violence due to the power imbalance inherent in abusive relationships. ${ }^{258}$ Parents who have been subjected to domestic violence may feel unable to freely and equally articulate their desires

255. See, e.g, D.C.Code AnN. § 16-914(a-1)(2014); Mo. AnN. StAT. § 452.375 (2014); NeV. Rev. StAT. AnN. § 125C.230 (2014); N.H. Rev. StAT. AnN. § 458:17 (2014); N.M. Stat. Ann. § 40-4-9.1 (2014).

256. See Daniel G. Saunders, Child Custody and Visitation Decisions in Domestic Violence Cases: Legal Trends, Research Findings, and Recommendations, VAWNET (1998), http://www. vawnet.org/applied-research-papers/print-document.php?doc_id=371, archived at $\mathrm{http}$ ://perma.cc/ 57QE-CU5H (stating that frequent contact when transitioning children between high conflict parents results in more verbal and physical abuse and is related to emotional and behavioral problems in children); Straus, supra note 253, at 230-49 (indicating that one of the most dangerous time for domestic violence victim is when picking up and dropping of children).

257. Leigh Goodmark, From Property to Personhood: What the Legal System Should Do for Children in Family Violence Cases, 102 W. VA. L. REV. 237, 277 (1999); Straus, supra note 253, at 230-49.

258. Jane C. Murphy \& Robert Rubinson, Domestic Violence and Mediation: Responding to the Challenge of Crafting Effective Screens, 39 FAM. L.Q. 53, 56 (2005); see also Leigh Goodmark, Autonomy Feminism: An Anti-Essentialist Critique of Mandatory Interventions in Domestic Violence Cases, 37 FLA. ST. U. L. REV. 1, 31 (2009) (arguing that in order to empower women they should be given the choice of whether or not to mediate). 
because they fear or remain under the control of abusive co-parents. ${ }^{259}$ Abusive parents may threaten their co-parents in ways that mediators, judges, or agency personnel fail to detect. ${ }^{260}$ Even if no new threats are levied, victimized parents may fear the fulfillment of past threats to kidnap a child, use custody proceedings to take a child away, or perpetuate further abuse if they act against the wishes of their former partners. ${ }^{261}$ Cases involving allegations of domestic violence could paralyze child support courts, or result in harmful outcomes where indications of domestic violence are missed, glossed over, or dealt with perfunctorily.

The federal parenting time proposals vary in their treatment of domestic violence concerns. The HHS proposed regulation makes no mention of the need for domestic violence safeguards in relation to the parenting time proposal. ${ }^{262}$ The Congressional resolution provides that the establishment of parenting time arrangements "should be accompanied by strong family violence safeguards."263 Likewise, the Obama Administration's budget proposal contemplates the need for special attention to cases involving a history of domestic violence, calling for states to incorporate domestic violence safeguards into parenting time plans. ${ }^{264}$ This is an important step, but a call for states voluntarily to impose safeguards alone is insufficient to protect the interests of parents and children exposed to domestic violence. Existing child support establishment processes are insufficiently resourced to effectively address custody and parenting time issues in cases involving a history of abuse, and the initiation of custody and parenting time proceedings could put some parents at risk of further abuse.

The risk of retributive violence in response to child support claims led Congress to encourage states to offer exemptions from the TANF child support enforcement program to recipients who establish "good cause," 265 including the risk of physical harm or serious emotional harm to the child or the recipient. Yet, despite the high rate at which TANF recipients report experiencing domestic violence, good cause exemptions are rare. ${ }^{266}$ The underutilization of good cause

259. Leigh Goodmark, Alternative Dispute Resolution and the Potential for Gender Bias, 39 No. 2 JUdGES' J. 21, 22 (2000) (noting the power imbalance between batterers and victims and that asking a batterer to "relinquish that power during mediation is unrealistic").

260. Susan Landrum, The Ongoing Debate about Mediation in the Context of Domestic Violence: A Call for Empirical Studies of Mediation Effectiveness, 12 CARDOZO J. CONFLICT RES. 425, 441 (2011).

261. Murphy \& Rubinson, supra note 258, at 56.

262. HHS 2014 Notice of Proposed Rulemaking, supra note 41.

263. 2014 Congressional Resolution, supra note 40.

264. Administration's FY 2014 Budget, supra note 37.

265. 45 C.F.R. $§ 232.41$ (2014); 42 U.S.C. $§ 608(c)$ (2014); 45 C.F.R. $§ 260.55$ (2014) (requirements for a federally recognized good cause waiver); 42 U.S.C. $§ 602$ (2014).

266. Jacqueline M. Fontana, Cooperation and Good Cause: Greater Sanctions and the Failure to Account for Domestic Violence, 15 WIS. WOMEN's L.J. 367, 380-81 (2000). The use of the "family violence option," which permits TANF recipients flexibility in meeting work and program requirements, is also low. See, e.g., Laurie Pompa, The Family Violence Option in Texas: Why Is It Failing to Aid Domestic Violence Victims on Welfare and What to Do About It, 16 TEX. 
exemptions likely stems from state agency procedural deficiencies as well as priorities and choices of recipients themselves. Case workers may not inform recipients about the good cause exemption, may discourage reporting of abuse by their demeanor, past interactions, or warnings about mandatory reporting requirements related to child abuse, ${ }^{267}$ and may deny exemptions to recipients who are unable to provide corroborating evidence. ${ }^{268}$ Recipients may choose not to pursue good cause exemptions because they need to receive child support to supplement TANF payments; ${ }^{269}$ are weary of disclosing such personal information to case workers for fear that case workers will not believe them or will report them for failure to protect children from violence; or are able to avoid child support collection without having to disclose abuse (for example, if they lack knowledge of a co-parent's whereabouts. $)^{270}$ The existing good cause mechanism has proved ineffective at identifying TANF recipient parents who have been subjected to domestic violence by a co-parent and providing an alternative option to the mandatory pursuit of child support. ${ }^{271}$ Alternative approaches would be imperative in the custody and parenting time context to ensure that parents are able to opt-out so that cases involving custody claims and a history of domestic violence are accorded the time and attention they require.

\section{EXPLORING ALternative SOLUTIONS-ENCOURAGING ACCESS WHILE PROTECTING FUNDAMENTAL RIGHTS TO STRUCTURE FAMILY ARRANGEMENTS}

The dual adjudicatory systems that have developed to allocate parental caretaking responsibilities provide substantively and procedurally different options for addressing issues related to children. Offering integrated custody,

J. WOMEN \& L. 241, 251 (2007).

267. As employees of state departments of human services or as social workers, case workers may be required to report information that leads them to believe a child has been abused or neglected to the state child protective services agency. See MANDATORY CHILD ABUSE REPORTING, 50 State Statutory Surveys (Westlaw 2015). In some states, information that a child has witnessed domestic violence perpetrated against a parent may give rise to an obligation to report child abuse or neglect. See, e.g., Nicholson v. Williams, 203 F. Supp. 2d 153 (E.D.N.Y. 2002).

268. Rachel J. Gallagher, Welfare Reform's Inadequate Implementation of the Family Violence Option: Exploring the Dual Oppression of Poor Domestic Violence Victims, 19 AM. U. J. GENDER SOC. POL'Y \& L. 987, 1002 (2011).

269. States have the option to "pass-through" portions of the child support collected in TANF cases to custodial parents on behalf of children. 42 U.S.C. $\S \S 644657$ (2015); see generally Michelle Vinson \& Vickey Turetsky, State Child Support Pass Through Policies, CTR. FOR LAW AND SOCIAL POL'Y (2009), http://www.clasp.org/docs/PassThroughFinal061209.pdf, archived at http://perma.cc/4CWG-EVTS.

270. See Nat'l Law Ctr. on Homelessness and Poverty, Shortchanging Survivors: THE FAMILY VIOLENCE OPTION FOR TANF BENEFITS (2009); U.S. GOV'T ACCOUNTABILITY OFFICE, supra note 246, at 8-9; see also Gallagher, supra note 268, at 1000.

271. NAT'L LAW CTR. ON HOMELESSNESS AND POVERTY, supra note 246, at 4-5. 
visitation, and child support options to all parents, regardless of income, marital status, or port of entry for court filing, is an important policy goal. However, such integration should not be shoe horned into the existing state child support adjudication process and masked as a simple, quick process by which parents develop "parenting time agreements" separate and apart from determining custody rights. Instead, states should develop integrated options for parents involved in state and private child support matters that are voluntary; treat both parents as parties; explicitly address custody and visitation rights; implement appropriate procedural safeguards; and offer clear legal information and assistance to ensure informed decisionmaking.

\section{A. Addressing Custody, Visitation and Support in State and Private Child Support Proceedings}

Whether parents enter the court system through the domestic relations portal or the parentage and child support establishment route, they should have the same opportunity to address issues related to support, visitation and custody in a coordinated, comprehensive fashion. The process used must respect fundamental parental rights and autonomy, ensuring careful consideration of each case in order to protect the best interests of children. Parents who are able to work out parenting arrangements voluntarily and without court assistance should not be forced or pressured to formalize these arrangements in court orders. Streamlined or alternative dispute mechanisms offering integrated adjudication should be available to parents, but not required, and only permitted where both parents consent. Where both parents do not consent, either parent should have accessible, efficient, low cost mechanisms for pursuing the custody or visitation issue in a domestic relations or other appropriate court. Integrated options in child support matters should be designed to ensure that parents have free and informed choice regarding whether to participate and state child support agencies should not be involved in determining custody or visitation arrangements.

Overloaded court dockets, understaffed family courts and overwhelming numbers of pro se litigants have spurred courts to develop new methods and resources for educating parents about rights and procedures for adjudicating domestic relations matters. ${ }^{272}$ Courts have established resource or self-help centers in which staff members are available to provide information and assist litigants in filling out simplified form pleadings. ${ }^{273}$ These resources should also

272. Jessica Dixon Weaver, Overstepping Ethical Boundaries? Limitations on State Efforts to Provide Access to Justice in Family Courts, 82 Fordham L. REV. 2705, 2708-11 (2014). See also Pro Se Resources by State, AMERICAN BAR AsSOCIATION, http://www.americanbar.org/ groups/delivery_legal_services/resources/pro_se_unbundling_resource_center/pro_se_resources _by_state.html (last visited May 6, 2015), archived at http://perma.cc/8F5T-GLHK.

273. See, e.g., Family Court Self Help Center; D.C. CourTs, http://www.dccourts.gov/ internet/public/aud_family/selfhelp.jsf(last visited Jan. 8, 2015), archived at $\mathrm{http}: / /$ perma.cc/37ATSMTQ; Pro Se Center, Cuyahoga Cnty DeP'T of Pub. SAFety and Justice Servs., http://ja.cuyahogacounty.us/en-US/mediation-services-new.aspx (last visited Jan. 8, 2015), archived 
be available in parentage and child support courts where integrating custody and parenting time agreements is contemplated. Both parents should have access to accurate, easy to understand legal information that explains parental rights and outlines the impact that a parenting arrangement has on each parent's custodial rights. Parents who do not understand that "parenting time" orders will result in the permanent distribution of custody rights might not approach or prepare for proceedings in the same way they would if they understood custody rights to be at stake. ${ }^{274}$ In addition, parents must be made aware of the effect that an increase or decrease in parenting time has on child support. ${ }^{275}$

Informational resources alone, however, would be insufficient to assist parents in navigating child support cases that integrate determinations of custody and visitation. ${ }^{276}$ In order to ensure that participation in a streamlined, integrated option is voluntary, courts and administrative agencies should partner with nonprofit organizations to provide information and advice to parents about whether they are good candidates for a streamlined process or whether they need more extensive court services. ${ }^{277}$

at http://perma.cc/ST7W-63BK; Family Law Facilitator, SUPERIOR CT. OF CALIFORNIA, ALAMEDA CTY., http://www.alameda.courts.ca.gov/Pages.aspx/Family-Law-Facilitator(1) (last visited May 6, 2015), archived at http://perma.cc/E648-YHHW.

274. Suzanne Reynolds et al., Back to the Future: An Empirical Study of Child Custody Outcomes, 85 N.C. L. REV. 1629, 1671 (2007) (explaining that when both parents are represented, the cases tend to settle, but in cases where one party is represented, litigation ensues).

275. Lauren Barth, Consultant Conduct in Anticipation of A Child Custody Evaluation: Ethical and Social Dilemmas and the Need for Neutral Parent Education, 49 FAM. CT. REV. 155, 162 (2011) (describing New York's Legal Information for Families Today ("LIFT)") Program that provides legal information for unrepresented clients). Other states also provide online information to potential pro se litigants. See, e.g., Child Custody and Visitation, VirTual Self-Help Law CTR., http://childcustody.cc-courthelp.org/index.cfm?fuseaction=Page.ViewPage\&PageID=1415\& stopRedirect=1 (last visited Aug. 2, 2014), archived at http://perma.cc/77NQ-MXCZ; Does Your Child Have A Legal Father? Paternity Information for Moms and Dads, MissouRI DEP'T OF SOCIAL SERVS., http://dss.mo.gov/cse/father0705.htm (last visited Aug. 2, 2014), archived at https://perma.cc/J7EY-5H7M?type=source; Handbook for Non-Custodial Parents, ATTORNEY GENERALOFTEXAS, https://www.texasattorneygeneral.gov/AG_Publications/pdfs/qa_ncp.pdf(last visited Aug. 2, 2014), archived at https://perma.cc/9N38-UH76.

276. Studies have demonstrated that providing informational materials and form pleadings can be inadequate to inform people about their rights. See, e.g., NONCUSTODIAL PARENTS, supra note 111, at 28-29.

277. Programs such as the Child Support Community Legal Services Project, a court annexed legal resource center located at the Superior Court of the District of Columbia, administered by the D.C. Legal Aid Society and Bread for the City, offers general legal advice concerning litigation of paternity and child support cases. Project attorneys advice clients regarding the advantages and disadvantages of entering consent agreements in paternity and support cases versus proceeding with a contested evidentiary hearing. See Special Projects, Legal Aid SocIETy of THE DistRict of COLUMBIA, http://www.legalaiddc.org/special-projects (last visited May 6, 2015), archived at http://perma.cc/PBV6-UPCU. 
State agencies and courts also should partner with legal services providers that have the trust of the low income community to offer legal assistance to parents interested in integrated options. In New York's Strengthening Families Through Stronger Fathers Initiative, for example, child support agencies and social services organizations partnered with legal services agencies to ensure that fathers had access to legal assistance with custody, visitation, and child support issues. ${ }^{278}$ In other jurisdictions, legal services providers have partnered with local courts to develop limited advice as well as same day representation initiatives that offer unbundled legal services to litigants in child support cases. In Washington D.C., for example, the Legal Aid Society and Bread for the City, two nonprofit legal services providers, received funding from the D.C. Bar Foundation to establish a court-annexed limited legal assistance project for pro se litigants in parentage and support cases. ${ }^{279}$ Attorneys provide legal advice, assistance with negotiation and, in some cases, same-day representation to parents with cases scheduled on the parentage and support court docket. ${ }^{280}$

Similarly, legal services providers and other community-based organizations could counsel and assist parents in devising, negotiating and drafting workable custody and visitation arrangements to be incorporated in child support determinations. Comprehensive fact-finding and formal adjudication as well as legal assistance for parents should be available in those cases in which parents do not agree to or are not suitable for streamlined processes. ${ }^{281}$

State child support agencies should not be involved in developing or negotiating custody or visitation agreements between parents whose fitness is not at issue. ${ }^{282}$ The state does not represent the interests of individual parents and does not have a legitimate basis for encroaching on private childrearing decisions. Therefore, the state should not be considered a party or take a position with respect to custody or visitation. ${ }^{283}$

\section{B. Incorporating Mediation, Community Courts, and Other Forms of Alternative Dispute Resolution}

Mediation or other forms of alternative dispute resolution may offer promising methods for addressing interrelated issues of visitation and custody in parentage and child support cases. ADR mechanisms potentially minimize the adversarial nature of the interchange between parents who have unstable or

278. Kye LipPold et AL., Strengthening FAmiLies Through Stronger FAthers: FinAL IMPACT REPORT FOR THE PILOT EMPLOYMENT PROGRAMS 7-9 (2011), available at http://www. urban.org/UploadedPDF/412442-Strengthening-Families-Through-Stronger-Fathers.pdf, archived at http://perma.cc/N8D8-9XEJ.

279. Child Support Community Legal Services Project, Legal AID SocIETY, http://www. legalaiddc.org/special-projects/ (last visited Aug. 1, 2014), archived at http://perma.cc/5H2F-2FPR.

280. Id.

281. See PARENTing Time ORders, supra note 83 , at 3.

282. Roberts \& Allen, supra note 146, at 279.

283. Id. 
nonexistent relationships. ${ }^{284}$ In Cuyahoga County, Ohio, for example, there is a mediator located at the child support agency where administrative hearings take place who provides information on parenting plans and can initiate mediation intakes to determine suitability for the mediation program used in all domestic relations cases. ${ }^{285}$ In other jurisdictions, mediators are on site at the court to assist in developing voluntary parenting plans in custody cases. ${ }^{286}$

In other countries mediation rather than litigation is the primary vehicle used to resolve parental access and custody, disputes for families of all socioeconomic backgrounds. In Australia, for example, a major overhaul of the family law system took place beginning in 2006, which resulted in the creation of sixty five Family Relationship Centres throughout the country designed to facilitate the resolution of post-separation disputes between parents without resort to the court system. ${ }^{287}$ These centers built on a tradition in Australia of court-based counseling services in the Family Court, federally funded relationship counseling programs, and community-based mediation services for separated parents. ${ }^{288}$

However, caution in using a mediation approach is warranted. Mediation of visitation and custody issues in child support cases has the potential to strain already limited court resources. Mediation can also be misused as an end rather than a means to resolving family matters when judges pressure parents to settle in mediation even though the parties are not suitable for the mediation process or the issues are not amenable to mediated solutions. ${ }^{289}$ In addition, to be successful, mediators must understand the context of the lives of the litigants in

284. See, e.g., Stephen K. Erickson, If They Can Do Parenting Plans, They Can Do Child Support Plans, 33 WM. MitcheLL L. REV. 827, 837, 852-60 (2007) (Erickson argues that current statutory support models are flawed because they are tied to rigid concepts based on custody status or time spent with children rather than recognizing the monetary and non-monetary contributions of both parents. He suggests that parents develop a mediated child support plan, akin to a parenting plan, using a method such as the Children's Checkbook method.); Kohn, supra note 120, at 546-53.

285. PARENTING TIME ORDERS, supra note 83, at 3.

286. See, e.g., Custody Mediation, CALIFORNIA COURTS, http://www.courts.ca.gov/1189.htm (last visited Aug. 13, 2014), archived at perma.cc/R2T6-Z5UA.

287. Patrick Parkinson, The Idea of Family Relationship Centres in Australia, 51 FAM. CT. REV. 195, 197 (2013) ("The concept behind the Government's investment in FRCs is that when parents are having difficulty agreeing on the post-separation parenting arrangements, they have a relationship problem, not necessarily a legal one. If no other solution can be found, the dispute may need to go to an adjudication by someone who can make a binding decision. However the issue should not be seen as a legal one from the beginning and the pathway to resolution should not be assumed to be a court-based or court-mandated process. Barring key exceptions such as urgency and safety issues, courts ought to be seen as a residual rather than a mainstream resource for managing or resolving disputes.").

288. Id . at 197; see also Huntington, supra note 51, at 231-33 (identifying Family Relationship Centres as an example of an institution "to help unmarried parents transition from a romantic relationship to a co-parenting relationship").

289. Engler, supra note 217, at 2007; Murphy, supra note 72, at 922. 
state and private child support cases. ${ }^{290}$ Mediators must not only be versed in domestic relations and support law but also in the complex family dynamics and pressures experienced by unmarried parents who have limited resources. ${ }^{291}$ Family mediation models geared toward married couples who have co-parented in the past and must now establish post-separation caretaking and support arrangements will not necessarily be appropriate. ${ }^{292}$ Mediators must also have the cultural awareness and understanding necessary to assist litigants to resolve matters in a way that the parties perceive as fair and just. ${ }^{293}$

Community courts provide an alternative vehicle for addressing custody, visitation and support issues, a vehicle that may foster more trust in the judicial process among the many low-income, unmarried litigants in state and private child support cases. Parents often express concern that those adjudicating and mediating their cases in traditional courts do not understand their family situations. ${ }^{294}$ Community courts are located in the neighborhoods where litigants live and are staffed by mediators and adjudicators who reside in the community and are familiar with the realities confronted by those seeking justice. ${ }^{295}$ Given their understanding of the context of litigants' lives and the obstacles they face, community mediators and adjudicators are arguably in a better position to resolve matters in ways that are respected by the parties as fair and just. ${ }^{296}$

In the United States, community courts have developed largely in response to outbreaks of crime and violence in particular neighborhoods. ${ }^{297}$ Such courts aim to devise realistic resolutions to disputes and thereby prevent further crime and promote community cohesion. ${ }^{298}$ Community courts also are proliferating

290. Jane C. Murphy \& Jana B. Singer, Divorced from Reality: Rethinking Family Dispute Resolution (unpublished manuscript) (on file with author) (anticipated publication June 2015, NYU Press).

291. See generally Huntington, supra note 51, at 185-96.

292. Murphy \& Singer, supra note 290; see also Huntington, supra note 51, at 205-09.

293. Murphy \& Singer, supra note 290.

294. These community courts are different from the prolific problem-solving drug and juvenile courts, which are located in state trial courts and staffed by judges and court personnel. BUREAU of Justice Assistance, Office of Justice Programs, U.S. Dep'T of Justice, Community COURTS: AN EVOLVING MODEL 6 (2000), available at https://www.ncjrs.gov/ pdffiles1/bja/183452.pdf, archived at https://perma.cc/HDY9-XWTJ. The community courts use less punitive and more rehabilitative remedies to change behavior. Id. at 16 . These courts focus on providing holistic, comprehensive services to enable parties to address the underlying causes of their criminal conduct so that they can avoid entanglements with the justice system. Id.

295. See Karen Tokarz \& V. NAGARAJ, AdVANCIng Social Justice Through ADR AND

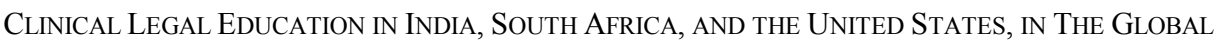
Clinical Movement: EduCATing LaWyers For Social Justice 253 (Frank S. Bloch ed., 2011).

296. See infra note 297 and accompanying text.

297. Bureau of Justice Assistance, supra note 294, at 3.

298. Id.; see also Greg Berman, Principles of Community Justice: A Guide for Community Court Planners, CTR. FOR COURT INNOVATION, http://www.courtinnovation.org/ sites/default/files/ Communitycourtprinciples.pdf (last visited Aug. 2, 2014), archived at http://perma.cc/ERB4- 
in countries such as India, where large disparities in wealth and high concentrations of poverty are reflected in the inefficient and often inequitable meting out of justice for low-income litigants. ${ }^{299}$ Observers report that the trust that litigants have in the adjudicators, in addition to the community pressure that is placed on litigants to adhere to the tribunal's decisions, lead to high levels of compliance with community court orders. ${ }^{300}$

A community court specifically addressing child custody, visitation and support may render more relevant and appropriate resolutions of disputes for families involved in state and private child support cases. Although further research would be necessary to document the actual impact of such courts, they hold the promise of promoting family cohesion and respect for the fairness of outcomes.

\section{Institute Procedural Safeguards to Ensure Due Process, Prevent Manipulation of Outcomes, and Protect Families in Situations of Domestic Violence}

To develop a meaningful process for addressing parenting time in the child support context, courts and administrative agencies must implement procedures that safeguard due process and protect parents and children from manipulation. First and foremost, both parents must be considered parties in state-initiated proceedings. Assigning party status to both custodial and noncustodial parents would ensure that both parents receive adequate notice and opportunity to be heard on issues related to caretaking of children.

Secondly, courts should require that child support orders incorporating custody/visitation agreements be temporary to monitor whether parties follow through on their obligations. Reviews of such orders could be set at reasonable intervals such as three to six months, to ensure that any decrease in support based on commitments of shared parenting are actualized. These safeguards prevent parents from committing to increased visitation or shared parenting as a means for reducing their support, leaving custodial parents with a cumbersome remedy for modifying the order. These reviews could take place in more informal

CDTP. In September 2013, the National Center for State Courts released a review of a model community court in Brooklyn, New York entitled the "Red Hook Model." CYNTHIA G. LEE ET AL, CENTER FOR COURT INNOVATION, A COMMUNITY COURT GROWS IN BROOKLYN: A COMPREHENSIVE Evaluation of the Red Hook Community Justice Center, FinAl Report 23-33, (2013), available at http://www.courtinnovation.org/ sites/default/files/documents/ RH\%20Evaluation\%20Final\%20Report.pdf, archived at http://perma.cc/UC4Z-9ZC3. The Model centered on three goals: deterring criminal behavior, intervening in problematic behavior using measures such as supervised drug treatments, and enhancing judicial legitimacy in an effort to strengthen community adherence to the law. Id. at 4.

299. Amitabha Bhattasali, India First Women's Court Opens in West Bengal, BBCNEws (Jan. 24, 2013), http://www.bbc.com/news/world-asia-india-21175738, archived at http://perma. cc/TKH8-LXTE.

300. $I d$. 
settings such as community based organizations or mediation centers so long as parents retain their ability to seek more formal redress or modification if the temporary order is not functioning as anticipated.

Finally, state agencies must improve the screening process for opt out and waiver in cases involving domestic violence. Parents who have been subjected to domestic violence by co-parents should have the ability to opt-out of mediation or adjudication of custody and visitation issues in support proceedings. ${ }^{301}$ Postseparation, abusive ex-partners often use custody litigation as a tool to continue to exert control and instill fear. ${ }^{302}$ An opt-out is essential to ensure that custodial parents have the opportunity to pursue the financial relief that is often critical to autonomy from an abusive partner, ${ }^{303}$ without mandating the increased contact and communication that often results from parenting time schedules and jeopardizes the safety of these parents and their children. ${ }^{304}$

Parents must be fully informed about opt out and waiver options to ensure that decisions regarding whether or not to address custody and visitation issues are fully informed. To increase the likelihood that custodial parents will feel comfortable disclosing abuse, child support agencies and courts should partner with advocacy organizations to conduct screenings and educate parents about their options. ${ }^{305}$ Given the widespread inefficacies of current state child support agencies' domestic violence waiver options, the federal Office of Child Support Enforcement should fund a number of pilot programs to innovate and test new mechanisms for identifying parents who qualify for opt-outs, informing them of their options, and supporting their choices.

Establishing such an opt-out would not preclude a noncustodial parent from initiating his own case for custody and parenting time (as is true under the current system), but an effectively designed and implemented opt-out will allow parents who have been abused to weigh independently which remedies are worth the risks they may pose. ${ }^{306}$ When parents who have experienced abuse want to pursue custody and parenting time, the matters should be referred to courts equipped to engage in the careful scrutiny of cases necessary to ensure that safety and relative bargaining power are taken into account when fashioning custody and visitation orders.

301. Susan Notar \& Vicki Turetsky, Models for Safe Child Support Enforcement, 8 AM. U. J. GENDER SOC. POL'Y \& L. 657, 677 (2000).

302. Mary Przekop, One More Battleground: Domestic Violence, Child Custody, and the Batterers' Relentless Pursuit of Their Victims Through the Courts, 9 SEATtLE J. Soc. Just. 1053, 1060-72 (2010).

303. Notar \& Turetsky, supra note 301 , at 661-62.

304. Id. at 707 .

305. Id. at 674-76.

306. Goodmark, supra note 259, at 43 (arguing that mandatory interventions in domestic violence cases could negatively affect a victim depending on individual circumstances and therefore interventions should only be made at the victims' discretion). 


\section{Prioritizing Programs that Directly Incentivize or Supplement Economic Support of Children}

Rather than focusing on formalizing parenting time arrangements as a mechanism for increasing formal child support compliance, particularly when further research on whether a causal connection exists is still needed, ${ }^{307}$ Congress and OCSE should prioritize and expand funding for initiatives that directly enhance the earning capacity of parents and address the structural poverty issues underlying low wage earners' struggle to support their children. Such initiatives include employment assistance programs for noncustodial parents, recognition of in-kind support and limited child support assurance. ${ }^{308}$

States have developed successful models for providing employment and related supportive services. In New York's Strengthening Families Initiative, for example, state child support agencies, social services organizations, and legal services providers partnered to help noncustodial parents obtain employment training as well as other supportive services such as legal assistance for those fathers seeking custody or visitation or for those needing legal help removing barriers to employment such as expunging of criminal records. ${ }^{309}$ The empirical evidence evaluating the success of this program was generally positive, though the degree to which compliance with support orders increased was mixed and depended on the employment experience of participants. ${ }^{310}$ Courts also increasingly have taken a "problem solving" approach to encouraging compliance with child support obligations. In Georgia, for example, a problem-solving child support court offers referrals to employment programs for unemployed noncustodial parents. ${ }^{311}$ The program helped fathers obtain employment and increased child support compliance rates. ${ }^{312}$ Virginia, North Carolina, Washington, D.C., and Pennsylvania have adopted similar models. ${ }^{313}$ As state

307. See supra notes $130-33$ and accompanying text.

308. There is a need to strengthen earning capacity in order to increase likelihood of visitation. See Maldonado, supra note 114, at 1022.

309. See Karin Martinson \& Demetra Nightingale, Ten Key Findings from Responsible Fatherhood Initiatives, URBAN INSTITUTE (Feb. 2008), http://www.urban.org/UploadedPDF/ 411623_fatherhood_initiatives.pdf, archived at $\mathrm{http}: / /$ perma.cc/V49Q-KCR7; LIPPOLDET AL., supra note 278 , at $4-5$.

310. LIPPOLD ET AL., supra note 278, at 4-5, 25-29.

311. Georgia Fatherhood Program, GA. DEP'T OF HuMAN RESOURCES, http://www.southernjudicialcircuit.com/fatherhood.pdf (last visited Aug. 3, 2014), archived at http://perma.cc/U8XF-MUE2.

312. Jasper J. Foust, An Evaluation of the Fatherhood Program at Middle Georgia Technical College (Jan. 2007) (unpublished Ph.D. dissertation, Capella University) (on file with author).

313. See Pathways to Responsible Fatherhood, KIRSA, http://www.kisra.org/programs/ employment/Pathways/index.html (last visited Aug. 13, 2014), archived at http://perma.cc/52BPYUKK; Responsible Fatherhood State Profile: North Carolina, U.S. DEP'T OF HEALTH AND HUMAN SERVS.: ADMIN. FOR CHILDREN AND FAMILIES (July 2009), http://library.fatherhood.gov/ cwig/ws/library/docs/FATHERHD/Blob/65457.pdf?w=NATIVE $\% 28 \% 27 \mathrm{BASIC}+$ ph+is+\%27\% 
budgets continue to contract, federal support of this type of program is more critical than ever. ${ }^{314}$

OCSE also should encourage states to acknowledge the many ways in which noncustodial parents financially support their children by recognizing in-kind contributions. OCSE could encourage states to expand the definition of child support to include in-kind contributions and fund pilot projects to implement and evaluate this practice. Increased recognition of in-kind contributions could have the added benefit of facilitating interaction of fathers with children. ${ }^{315}$ Many custodial parents recognize that noncustodial parents who provide in kind and direct contributions to children are, at least in part, fulfilling their responsibilities to support their children. ${ }^{316}$ Scholars such as Solangel Maldonado have suggested a system of crediting in-kind and non-financial contributions against formal child support orders. ${ }^{317}$ This system would not only incentivize providing direct economic support for children, but could incentivize noncustodial parent contact with children by conditioning the credit on the noncustodial parent visiting with and assisting with the caretaking of the child. ${ }^{318}$

Although it is important to increase employment assistance opportunities for noncustodial parents and credit their in-kind contributions, low-income custodial parents are left in a vulnerable economic position if they receive minimal or no direct financial assistance from the other parent as a result. Unless noncustodial

27 state + profile $\% 27 \% 27+$ AND + TI + ph + is $+\% 27 \% 27$ North + Carolina $\% 27 \% 27 \% 27 \% 29 \& u p p=0$ $\& \mathrm{rpp}=25 \&$ order $=$ native $\% 28 \% 27$ year $\% 2$ FDescend $\% 27 \% 29 \& \mathrm{r}=1 \& \mathrm{~m}=1$, archived at http://perma.cc/4L4Q-333R; see also Promoting Responsible Fatherhood, PRIMARY CARE HEALTH SERVICES, INC., http://pchspitt.org/programs/fatherhood.php (last visited Aug. 13, 2014), archived at http://perma.cc/5U6J-NVYC. The D.C. Court focuses on fathers reentering after incarceration. See Honorable Milton C. Lee, Fatherhood in the Child Support System: An Innovative Problem Solving Approach to an Old Problem, http://www.dccourts.gov/internet/documents/2012-0101Fathering-Court-Article-Published.pdf(last visited Aug. 13, 2014), archived at http://perma.cc/ 435J-EPB2.

314. Evaluations of employment assistance programs for non-custodial parents suggest that successful programs have certain elements in common: i) employment services personnel are located in courts or at child support agencies; ii) child support staff are located on-site at employment assistance centers; and iii) job training, apprenticeship and education opportunities (such as GED) are available. In addition, successful programs use incentives such as temporary reduction of support, reinstatement of driver's licenses, transportation assistance and work stipends. Agencies conduct effective follow-up, monitor compliance of participants, refer participants to a range of supportive services and impose meaningful sanctions for non-participation. Evaluators have noted that success may be attributed in part to participation in a particularly well-designed program and in part to the motivation level of the noncustodial parent. See Stacy Brustin, Child Support: Shifting the Burden in Low Income Families, 20 GEO. J. Pov. L. \& Policy 1, 42-43 (2012).

315. See Maldonado, supra note 114, at 1016.

316. See id. at 1016-17; but see Nepomnyaschy \& Garfinkel, supra note 117, at 30-32.

317. Id. at 1016-17; see also Kohn, supra note 120, at 542-43.

318. See Maldonado, supra note 114, at 1018-19. 
parents can enhance their earning capacity, (rather than simply securing any low wage job available) those working full time at or near the minimum wage will qualify for a low-income adjustment under most state child support guidelines and will pay as little as $\$ 50$ per month in support. ${ }^{319}$ Enhancing earning capacity and addressing other barriers to securing higher paying employment take time. In the interim, low-income custodial parents, particularly those that are leaving or have left TANF, struggle to subsist with little or no financial support from the noncustodial parent. Therefore, there is a need to provide families with child support supplements, at least on a temporary basis, to enable custodial parents to provide shelter, food and other costly essentials for families during the time that they are receiving solely in-kind or minimal cash contributions from the noncustodial parent.

One possibility would be to provide an interim boost, in the form of a benefit or tax credit, to families when the custodial and/or noncustodial parent is participating in a work program designed to strengthen the parent's earning capacity and employability. ${ }^{320}$ Another option for providing support assurance while continuing to incentivize work for noncustodial parents would be to provide meaningful stipends or wages for government sponsored employment training or community works projects, which could then be used to provide financial support for children. ${ }^{321}$ This type of interim incentive program has the potential to encourage parents to strengthen their earning capacity while ensuring a minimal standard of living for low-income custodial parent families.

\section{CONCLUSION}

The goal of recapturing costs expended on public assistance historically has driven federal child support policy. The mission to recapture cost has come at the expense of the autonomy of low-income parents who, as a condition of receiving benefits, assign their right to make financial caretaking and health insurance coverage decisions to the state. As the TANF rolls have dwindled, the mission of the federal child support program has begun to shift from cost recapture to promotion of stability and financial independence for families. State agencies increasingly are seeking ways to offer employment assistance, expand the earning capacity of parents, facilitate access of parents to children, and set realistic support orders to benefit families directly and prevent future welfare dependence.

319. Brustin, supra note 314 , at 20-23.

320. See id. at 48-51; Huntington, supra note 51, at 234-35. Although a full exploration of the promises and challenges of implementing and funding child support supplements is beyond the scope of this paper, for a more detailed explanation of the potential impacts of and barriers to implementation of an "assured child support benefit," see Irwin Garfinkel et al., Findings of the Wisconsin Child Support Reform Project: Introduction and Summary, CHILD SUPPORT ASSURANCE Design Issues, EXPeCted Impacts, AND Political BarRiers as SEEN From Wisconsin 1, 5 (1992).

321. See Brustin, supra note 314 , at 50. 
The proposition that the increased access of fathers to their children leads to greater child support compliance has gained particular prominence in recent years and has led the Obama Administration and members of Congress to recommend that "parenting time provisions" be incorporated in state-initiated child support actions. The intentions behind these proposals may be laudable and the goal to offer parents involved in the child support process the ability to address all caretaking issues regarding their children in one proceeding is overdue. But the federal "parenting time" proposals put forth in the Administration's Budget and the HHS proposed regulation threaten to usurp the autonomy that unmarried parents currently retain to allocate caretaking responsibilities. The proposals also risk weakening the quality of custody and visitation adjudications for low income, unrepresented litigants, and increasing the potential for coercion and harm in cases with a history of domestic violence. The potential benefits of these policies pale in comparison to the risks they pose. Rather than pursuing simplified solutions, policymakers should adopt a multilayered approach that supports parents in addressing their financial and caretaking needs while respecting the integrity of their choices. 